\title{
A review of recent advances towards the development of QSAR models for toxicity assessment of ionic liquids
}

\author{
Natalia Abramenko ${ }^{\mathrm{a}, \mathrm{b}}$, Leonid Kustov ${ }^{\mathrm{a}, \mathrm{c}}$, Larysa Metelytsia ${ }^{\mathrm{d}}$, Vasyl Kovalishyn ${ }^{\mathrm{d}}$, Igor Tetko ${ }^{\mathrm{e}}$, \\ Willie Peijnenburg, ${ }^{\mathrm{f}, \mathrm{g}, *}$ \\ ${ }^{a}$ N.D. Zelinsky Institute of Organic Chemistry, Russian Academy of Sciences, Moscow, Leninsky prospect 47, 119991, Russia \\ ${ }^{\mathrm{b}} \mathrm{N}$. Severtsov Institute of Ecology and Evolution, RAS, Moscow, Russia \\ ${ }^{\mathrm{c}}$ National University of Science and Technology MISiS, Leninsky prosp. 4, Moscow, Russia \\ ${ }^{\mathrm{d}}$ Institute of Bioorganic Chemistry \& Petrochemistry, National Academy of Science of Ukraine, 1 Murmanska Street, 02660, Kyiv, Ukraine \\ ${ }^{\mathrm{e}}$ Helmholtz Zentrum München - German Research Center for Environmental Health (GmbH), Institute of Structural Biology, BIGCHEM GmbH, Ingolstädter Landstraße 1, \\ b. 60w, D-85764 Neuherberg, Germany \\ ${ }^{\mathrm{f}}$ Institute of Environmental Sciences (CML), Leiden University, PO Box 9518, 2300 RA, Leiden, the Netherlands \\ ${ }^{\mathrm{g}}$ National Institute of Public Health and the Environment, Center for Safety of Substances and Products, PO Box 1, 3720 BA, Bilthoven, the Netherlands
}

\section{A R T I C L E I N F O}

Editor: Danmeng Shuai

Keywords:

Ionic liquids

Computational toxicology

Hazard assessment

Green solvents

\section{A B S T R A C T}

- Ionic liquids (ILs) are considered as an alternative to traditional organic solvents due to their unique physical and chemical properties. On the one hand, they have promising solvating characteristics, on the other hand, they are considered as environmentally friendly "green" solvents. Recent studies of ILs toxicity however questioned the safety of ILs.

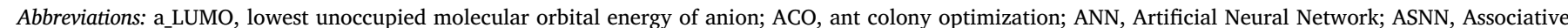

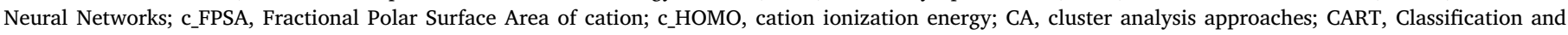

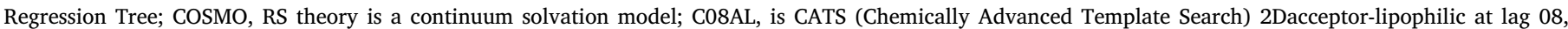

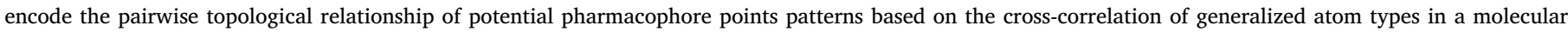

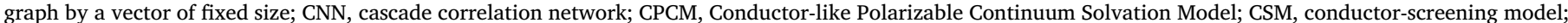

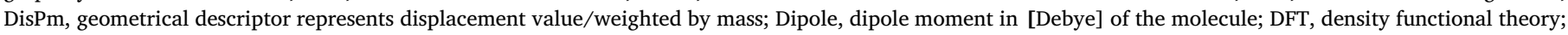

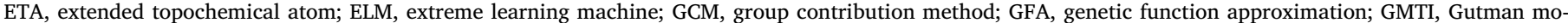

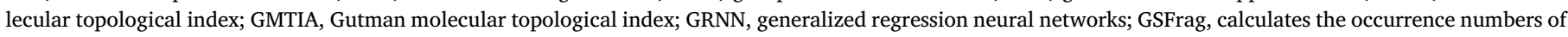

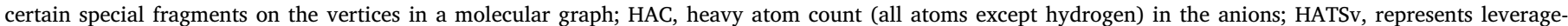

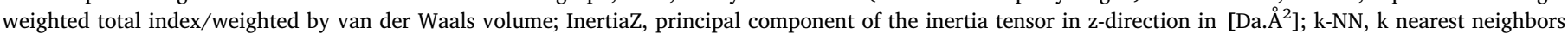

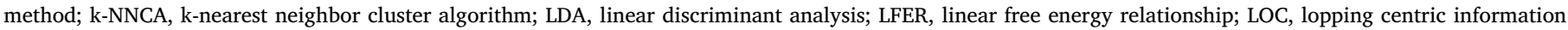

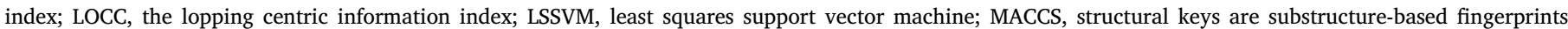

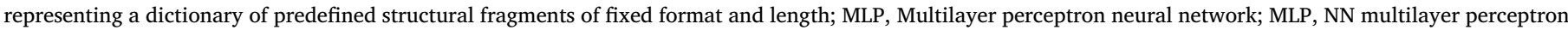

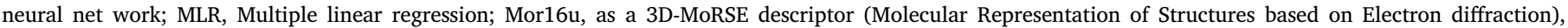

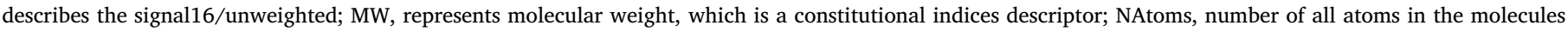

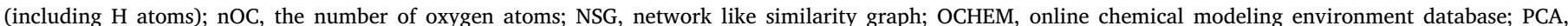

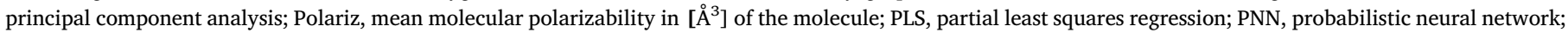

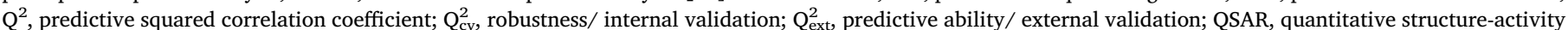

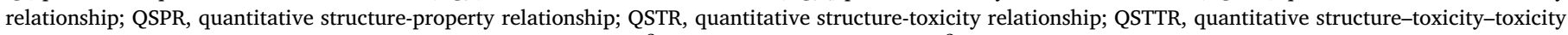

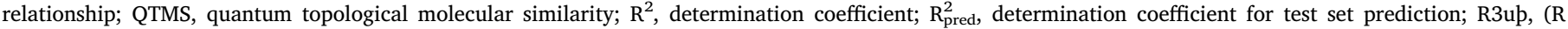

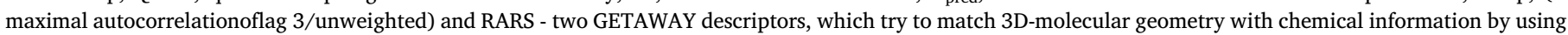

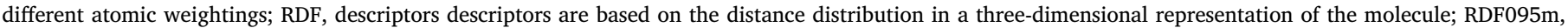

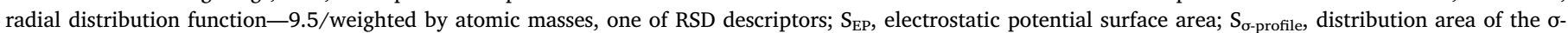

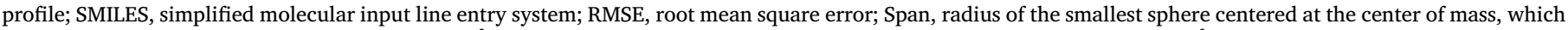

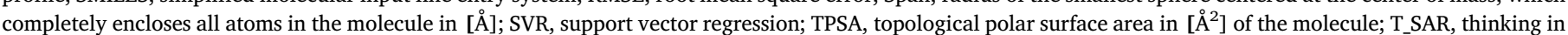

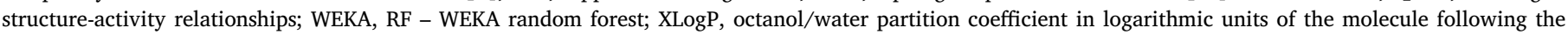
atomic contribution approach

* Corresponding author.

E-mail address: peijnenburg@cml.leidenuniv.nl (W. Peijnenburg). 

resources. Complementing this task by applying computational methods is an option for filling data gaps and allows predicting the toxicity of ILs that lack experimental data. Development and application of quantitative structure-activity relationships (QSARs) for innovative design of safe-by-design ILs became recently a research priority. In this review, we summarize the current knowledge on development of in silico models in predicting and classifying the hazards of ILs. In addition, we discuss biodegradability of ILs and assessment of mechanisms of toxicity of ILs based on the reported models.

\section{Introduction}

Ionic liquids (ILs) are suggested as a promising alternative to volatile organic liquids (Cvjetko Bubalo et al., 2014) that are a major source of environmental pollution (Salar-García et al., 2017; Thuy Pham et al., 2010). Nevertheless, ILs, sometimes called "green solvents", are not intrinsically safe as some of them are actually rather toxic, but they can be designed to be environmentally friendly (Egorova and Ananikov, 2014).

ILs consist mainly of a bulky non-symmetric organic cation incorporated into the structure of a salt together with a weakly coordinating anion. Imidazolium, ammonium, pyridinium, pyrrolidinium, phosphonium are the most widely used cations for the preparation of ILs, anions could be inorganic like $\mathrm{Cl}-,\left[\mathrm{BF}_{4}\right]-,\left[\mathrm{PF}_{6}\right]-$, Br-, or organic such as trifluoromethylsulfonate, bis(trifluoromethyl)sulfonylimide, and others. Combinations of various anions and cations give a tremendous number of ILs with unique properties. At least a million binary ILs can potentially be obtained (Rogers and Seddon, 2003).

ILs represent an attractive medium for various types of chemical processes due to their significant thermal stability, negligible vapor pressure, high conductivity, low volatility. ILs can be applied for electrode modification due to their hydrophobicity, ionic structure, and appropriate viscosity (Opallo and Lesniewski, 2011). ILs can find application in separation processes and electrochemistry. ILs received attention as solvents or electrolytes for utilization in energy storage and conversion, catalysis, organic synthesis, drug delivery (Fei et al., 2006; Plechkova and Seddon, 2019, 2008).

Nevertheless, owing to the good solubility of many ILs in aqueous media, they can be released into environment with wastewater (Torrecilla et al., 2009). There is therefore a significant concern that these chemicals may get in contact with living organisms, cause harm to biota and, eventually, human beings. Several studies showed that ILs can induce toxic effects in ecosystem (Samorì et al., 2007; Latała et al., 2009). Also, the risk of accumulation of high concentrations of ILs in environment due to their high stability to heat and other factors is a significant concern. Therefore, it is of relevance to monitor the behavior and biodegradation of ILs in environment and to get knowledge of the fate and effects of ILs for the environment.

Considering the time needed to perform experimental studies (Samorì et al., 2010), computational modeling (in-silico) methods may be a robust and less expensive alternative in the risk assessment of ILs. Methods of QSAR (quantitative structure-activity relationships) interlink the structural characteristics and properties of a substance, for instance, biological effects of chemicals in nature (Roy et al., 2015a). The QSAR approach provides a rapid possibility to fulfilling data gaps for limited or absent experimental information (Dearden, 2016). This computational method was applied successfully in different areas such as drug development, toxicity and pharmacy. Several attempts have been made to apply the QSAR approach to correlate the structure of ILs with their biological effects, cytotoxicity and degradation (Table 1). In this article, the present knowledge on the application of computational approaches in hazard assessment of ILs is reviewed. The main parts of this review are the following:

- Section 2 illustrates the progress in understanding the degradation of ILs according to the published works and experiments/
- Section 3 is dedicated to an overview of published computational models with information about the used datasets and database, sources, tested animals and cell lines.

- Section 4 summarizes the current knowledge of the relationship between the structure of ILs and their biological activity

- Section 5 resumed QSAR/QSPR models based on different modeling approaches such as non-linear and linear regressions (PLS, SVR, MLR, KNN, WEKA, ANN). Finally we discuss possible mechanisms of toxicity of ILs based on published models and provide an outlook for future research in prediction of ILs toxicity and biodegradation.

\section{Ionic liquids degradation}

Understanding and quantification of degradation and biodegradation parameters of ILs (Arning et al., 2008) is very important to enable decreases of their potential exposure. Research results on biodegradation and chemical degradation studies of ILs (Awad et al., 2004; Peric et al., 2013; Li et al., 2007; Siedlecka and Stepnowski, 2009) demonstrated that the percentage of degradation is strongly dependent on the length of the alkyl side chain, core ring structure, and the presence of functional groups (Neumann et al., 2012; Docherty et al., 2007), while the role of the anion is less important (Stolte et al., 2011). It was observed that cations with short side chains are not biodegradable (Peric et al., 2013; Docherty et al., 2007; Stolte et al., 2011; Andrew et al., 2006; Romero et al., 2008; Coleman and Gathergood, 2010; Jordan and Gathergood, 2015). Several authors demonstrated that phosphonium ILs are better degradable than imidazolium and pyridinium ILs (Neumann et al., 2012; Stolte et al., 2011; Garcia et al., 2005; Gathergood et al., 2006; Markiewicz et al., 2009; Liwarska-Bizukojc et al., 2014). Furthermore, it was indicated (Oliveira et al., 2016) that protic ILs have poor biodegradability. Fig. 1 depicts the pattern of parameters affecting the biodegradation of ILs.

Commonly used ILs are not easily biodegradable and might accumulate in environment in case of an accidental release (Docherty et al., 2007). However, some naphthenic acid-derived ILs can be rapidly and completely biodegraded in aquatic environments under aerobic conditions (Yu et al., 2008).These authors investigated the structure and properties of these ILs and made an attempt to build a predictive model of biodegradation. For this purpose, four descriptors were chosen: the logarithm of the n-octanol/water partition coefficient (logP), van der Waals volume (VvdW), energy of the highest occupied molecular orbital $\left(\mathrm{E}_{\mathrm{HOMO}}\right)$, and energy of the lowest unoccupied molecular orbital ( $\left.\mathrm{E}_{\text {LUMO }}\right)$. According to the developed Quantitative Structure-Biodegradation Relationship model, $\mathrm{E}_{\mathrm{HOMO}}$ was suggested as an important parameter in the discovery of other biodegradable ILs:

Extent of biodegradability $=119.294+37.821 * \mathrm{E}_{\mathrm{HOMO}}$

$\mathrm{n}=10, \mathrm{R}=0.875$

In summary, it was proposed that hydrophobic, steric, and electronic parameters are responsible for biodegradability of ILs. These properties determined the possibility of ILs to penetrate through membrane barriers, their ability to interact with active sites of oxygenase, and the potential of being oxidized and degraded. ILs may insert into the lipid bilayer of the membrane and may disturb structural and dynamical systems of bio-membranes (Yoo et al., 2016). For instance, 


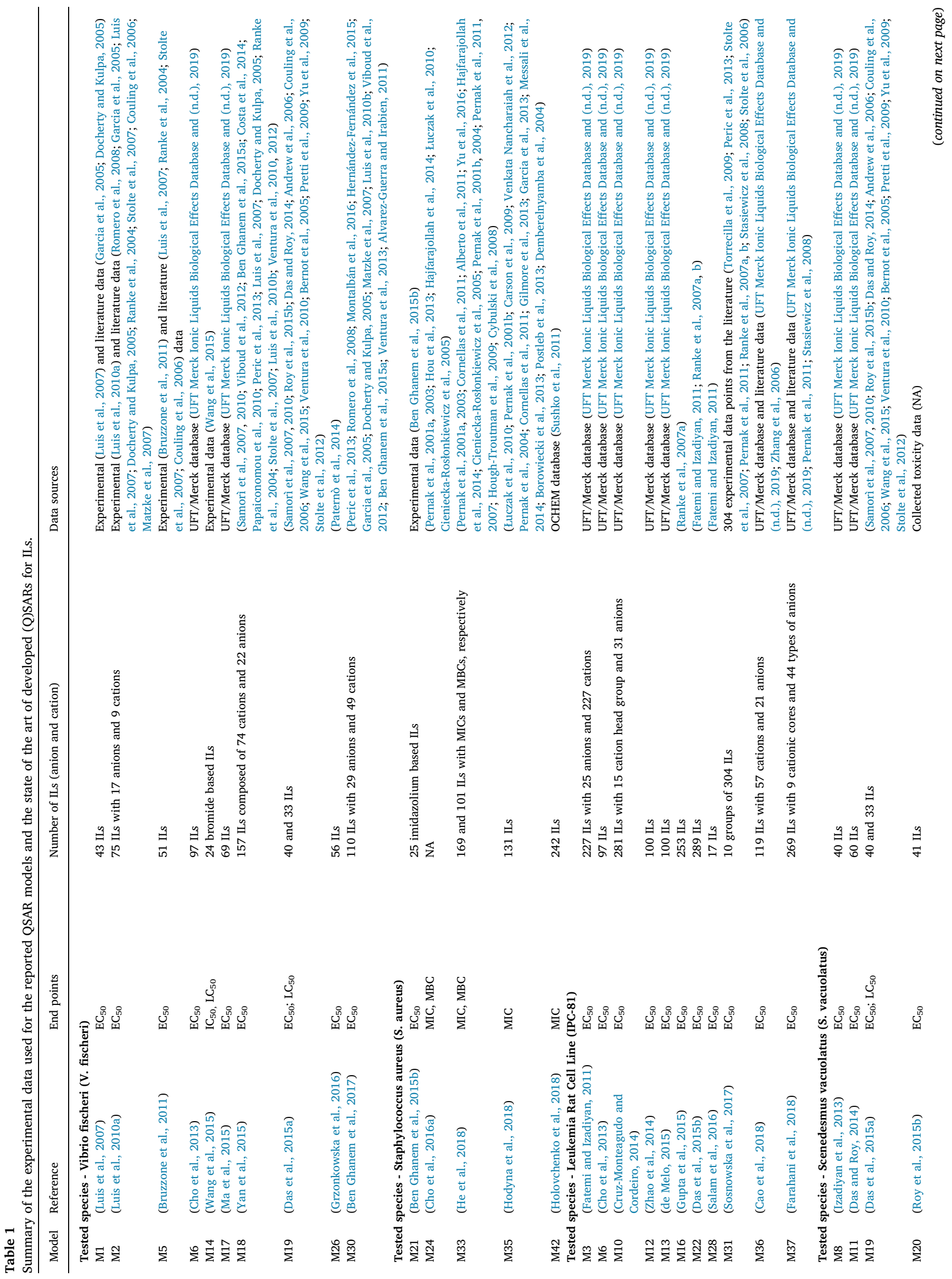




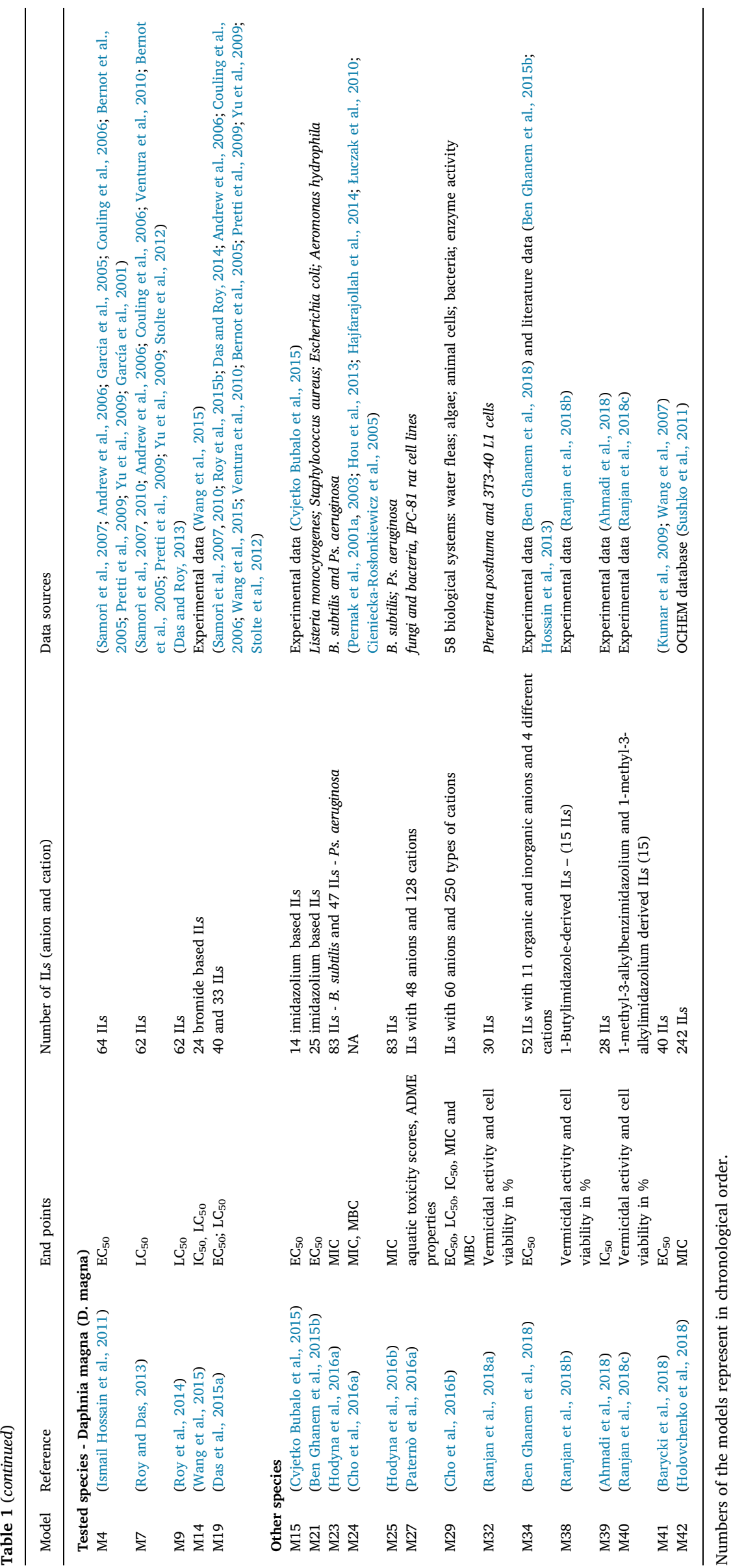




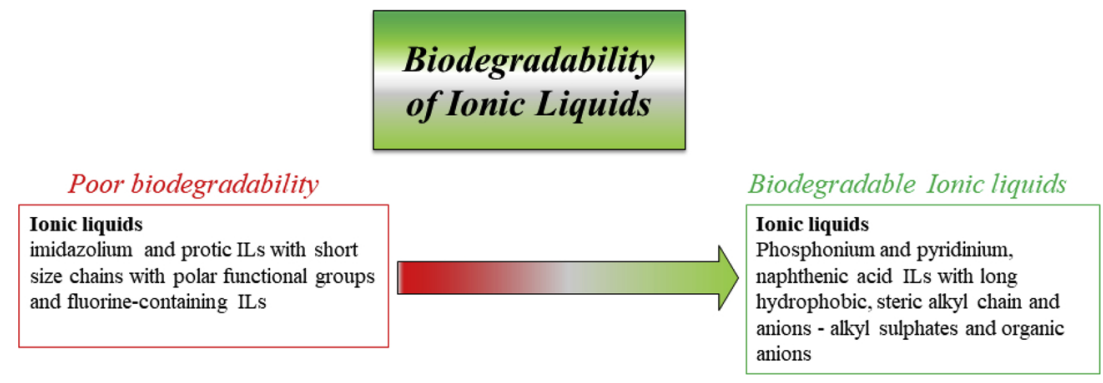

Fig. 1. Interpretation of biodegradability of ILs with respect to their structural features.

ILs may act as end-capping agents for the hydrophobic edge of the lipid bilayer (Baker et al., 2014) and may cause swelling of the lipid bilayer. The interaction of ILs is strongly correlated with the hydrophobicity of the IL cationic alkyl chain and anions, and these parameters determine the dependences observed in studying IL cytotoxicity (Baker et al., 2014).

\section{State of the art of in Silico models applied for hazard assessment of ionic liquids}

A literature search was performed until February 2019 using the ScienceDirect, PubMed databases and the Web of Science ${ }^{\mathrm{TM}}$ using the search terms "ionic liquid modeling", "ionic liquid toxicity QSAR", "ionic liquid QSTR modeling" and "ionic liquids QSAR" in the title, abstract or keywords. In this part, the obtained data are presented and the state of the art of development of QSAR models for toxicity of ILs is analyzed. Table 1 summarizes endpoints and number of in the datasets, tested organisms, and data resources that are described in the articles devoted to modeling the toxicity of ILs.

\subsection{Development of QSAR models for ionic liquids}

According to the literature, there is a wide variety of organisms with different sensitivity to ILs, whereas the sensitivity depends on the test duration. Main endpoints studied are related to three common effect levels, i.e. the concentration at which $50 \%$ of biota are affected $\left(\mathrm{EC}_{50}\right)$, minimal inhibitory concentration (MIC), and minimal biocidal concentration (MBC). MIC defines the lowest concentration, which prevents the growth of bacteria, MBC is the lowest concentration that leads to death of bacteria.

In the case of modeling the toxicity of ILs, V. fischeri and Scenedesmus vacuolatus were the most studied organisms. The cell line IPC-81 was chosen as one of the most often studied cell lines. Several studies reported results of modeling the critical micellar concentration (Barycki et al., 2017; Karakashev and Smoukov, 2017) and enzyme activity of ILs (Torrecilla et al., 2009; Arning et al., 2008; Sosnowska et al., 2014; Yan et al., 2012; Basant et al., 2015; Cho and Yun, 2016; Paternò et al., 2016b).

Most of models were developed on the basis of an average dataset size (about $100 \pm 50$ datapoints), several models were built using a dataset of 200-300 endpoints, whereas two models (M29 and M12) contained 1633 and 4000 datapoints, respectively.

\subsection{Databases of Ionic Liquids toxicity and data availability}

Specific databases of ILs toxicity are available, supplemented with physical, chemical, and biological properties of ILs (UFT Merck Ionic Liquids Biological Effects Database and (n.d.), 2019; Sushko et al., 2011; Zhang et al., 2006; Dong et al., 2007). The work with databases is a well-established essential component for the development of ILs hazard identification. To be useful for modeling purposes, databases must cover the chemical space of the known ILs. For QSAR modeling, databases must provide bioactivity data (cell-based assays or tested species) and data about chemical compounds tested in cell lines with their molecular structures in chemical file formats. Some of presented databases are collections of chemical structures and measured bioactivities and properties of ILs collected from literature such as the Online Chemical Modeling Environment (OCHEM) database (Sushko et al., 2011). In this database, the structure of ILs can be introduced as a mixture of separate ions presented by SMILES formula. The database contains antimicrobial datapoints (MIC values) for approximately 618 ILs.

The UFT/Merck database (UFT Merck Ionic Liquids Biological Effects Database and (n.d.), 2019) (http://www.il-eco.uft.uni-bremen.de $/)^{1}$ includes catalogues of commercially available data from screening toxicity assays. It contains information about the toxicity of over 300 different ILs and their precursors.

\section{Profiling green solvents such as ionic liquids based on in Silico Models}

One of main tasks of structure-activity models is identification of factors (signified by different descriptors) affecting the ILs toxicity and properties. The role of different factors should be discussed by analyzing the represented descriptors in the published models to draw a conclusion about the toxicity mechanism of ILs with respect to living organisms.

According to the models, phosphonium-based ILs are more toxic than their imidazolium analogs (Ventura et al., 2012). The contribution of the cation to the toxicity of ILs with respect of $V$. fischeri increases in the following order:

Pyrrolidinium < imidazolium < pyridinium (Luis et al., 2007).

The central role of the cation alkyl chain length was found for different types of organisms (E. coli, S. aureus, A. hydrophila and $L$. monocytogenes) used for toxicity assessment of ILs (Ben Ghanem et al., 2015b). ILs with a longer chain length show less eco-friendly behavior than ILs with cations containing hydroxyethyl or butyl chains. At the same time, toxicity decreases with introduction of amino acid anions compared with other anions $\left(\left[\mathrm{N}(\mathrm{CN})_{2}\right],\left[\mathrm{BF}_{4}\right],[\mathrm{Br}],[\mathrm{Cl}]\right)$ (Ben Ghanem et al., 2015b).

The contribution of the anion to the toxicity of ILs is still under investigation. Without considering the effect of anions, it can be assumed that pyridinium, (dimethylamino)pyridinium, tetramethylguanidinium and cholinium cations contribute in a similar manner to the toxicity with respect to V. fischeri (Luis et al., 2010a). With respect to the structure of the anion, it was found that chloridebased ILs are the least toxic for Scenedesmus vacuolatus (Fatemi and Izadiyan, 2011; Izadiyan et al., 2013). Ghanem (Ben Ghanem et al., 2015b) observed reduction of antimicrobial activity of ILs composed of 1-octyl-3-methylimidazolium and 1-(2-hydroxyethyl)-3-methylimidazolium cations with different anions towards $A$. hydrophila and $L$. monocytogenes in order:

$\left[\mathrm{N}(\mathrm{CN})_{2}\right]>[\mathrm{Br}]>\left[\mathrm{BF}_{4}\right]>[\mathrm{Cl}]>[$ Asparagine $]>$ [Glycine $]>$ [Alanine $]>$ [Proline $]>$ [Serine $]$.

\footnotetext{
${ }^{1}$ The database is disabled since 19 January 2019
} 
Additionally it was shown that [bis((trifluoromethyl)sulfonyl) imide] anion strongly increases toxicity of ILs towards Aeromonas hydrophila in contrast to other hydrophilic and amino acid derived anions (Ben Ghanem et al., 2018). The developed MLR models (Ben Ghanem et al., 2017) based on the $\sigma$-profile descriptors highlighted the difference between the minor and major effect of hydrophilic and hydrophobic anions. Furthermore, negatively charged atoms in the anion provide reduced cytotoxicity towards cell line IPC81 as compared to anions with positively charged atoms (Fatemi and Izadiyan, 2011).

Lipophilicity (Ben Ghanem et al., 2015b; Rybinska et al., 2016) is another important parameter that influences toxicity of ILs. Due to their strong lipophilic properties, phosphonium ILs are interfaced with the membrane of Escherichia coli cells (Cornmell et al., 2008). Increasing branching and the presence of $\mathrm{N}$-atoms in the cationic structure were proven to significantly increase toxicity towards $D$. magna and $V$. fischeri (Roy et al., 2014). Additionally, the molecular volume of the cation is the most significant factor determining ILs toxicity towards $E$. coli (Cho et al., 2016a). The second most important factor affecting the toxicity of ILs is related to hydrogen-bonding acidity and ionic interactions of the cation. The excess molar refraction (the function of interaction of $n$ - or $\pi$-electron lone pairs) and hydrogen bonding basicity of the cation are less significant for toxicity of ILs with respect to $E$. coli. It was suggested that the MIC and MBC values of ILs tested with $E$. coli were determined by lipophilic interaction and H-bonding interactions of the cation. Fig. 2 depicts the role of different structural characteristics according to the analyzed models.

\section{Critical analysis of QSPR/QSTR models}

Several predictive QSPR (Quantitative Structure-Property Relationships) and QSTR (Quantitative Structure-Toxicity Relationships) models were developed for risk assessment of ILs towards different biological species. Table 2 represents the summary of the used methods, descriptors and parameters of the developed models. The role of different structure characteristics (according to descriptors applied in the models) is analyzed.

Two types of models are presented in literature. One of them includes models developed to offer quantitative assessments for hazardous effects caused by ILs; the other models contribute to the categorization and labeling of substances according to their toxicity. Data of models as reported in Table 2 show that both types of models were developed for toxicity of ILs in respect to biota.

Hazard assessment and information on safe-by-design ILs can be retrieved from the frequency of applying a certain descriptor in the designed models of ILs toxicity. This information allowed one to discuss the role of different parameters in determining the hazardous properties of ILs for environment. With respect towards the type of descriptors, the published models can be labeled as models based on (i) quantum-chemical descriptors; (ii) other theoretical molecular descriptors, and (iii) quantitative structure-toxicity-toxicity relationship (QSTTR) models. The descriptors and structure fragments affecting the ILs toxicity are discussed below.

\subsection{Quantum-chemical descriptors-based models ${ }^{2}$}

The combined study based on experiments and QSAR modeling was performed for 24 bromide ILs towards $V$. fischeri and D. magna (Wang et al., 2015). According to the QSAR model for $V$. fischeri, toxicity was negatively correlated with $\mathrm{E}_{\mathrm{LUMO}}$; for $D$. magna, toxicity increased with increasing dipole moment and decreasing total energy. Models of cytotoxicity (cell line IPC81) of 17 ILs with imidazolium, pyrrolidinium,

\footnotetext{
${ }^{2}$ Quantum-chemical descriptors represent only descriptors that are calculated from the molecular structure by using ab initio and semi-empirical quantum chemical methods
}

and pyridinium cations were obtained by Salam (Salam et al., 2016). The models were developed with electrophilic indices $(\omega), \mathrm{E}_{\mathrm{homo}}$ and $E_{\text {lumo }}$, the energy gap as quantum chemical reactivity descriptors and based on the density functional theory (DFT). PCA analysis was carried out to access the distribution and inter-relation of descriptors of the model.

A predictive QSAR model of ecotoxicity of ILs with respect to $V$. fischeri was designed by Ghanem (Ben Ghanem et al., 2017) by using COSMO-RS descriptors. To obtain linear and non-linear QSAR models, the authors used a set of toxicity data $\left(\mathrm{EC}_{50}\right)$ for 110 ILs: a combination of 49 cations and 29 anions. A high prediction accuracy of 0.906 was obtained for the linear model. Five descriptors were selected from the linear model and used to develop the non-linear model by applying the multi-layer perceptron (MLP) technique. The accuracy of the constructed model was evidenced by the high correlation coefficient 0.961 and mean square error 0.157 . Another predictive model of the vermicidal activity and cell viability for 30 ILs with various alkyl chains was constructed (Ranjan et al., 2018a). It was stated that an increase in the alkyl chain length leads to an increase in the vermicidal activity.

The applicability of the extreme learning machine (ELM) model was compared with SVM and MLR methods for prediction of toxicity of ILs towards cell line ICP-81 (Cao et al., 2018). The electrostatic potential surface area $\left(\mathrm{S}_{\mathrm{EP}}\right)$ and charge distribution area $\left(\mathrm{S}_{\sigma \text {-profile }}\right)$ were used to predict toxicity of 119 ILs. The model obtained by ELM shows the highest value of $R^{2} 0.969$ in comparison with $R^{2} 0.92$ for MLR and 0.941 for SVM models. Experimental generation and subsequent modeling of toxicity of 15 1-butylimidazolium ILs was performed using LUMO of the anion and the fractional polar surface area of the cation as descriptors (Ranjan et al., 2018b). Based on the results (Ranjan et al., 2018c) showing strong relationship between cytotoxicity and vermicidal activity of 1-methyl-3-alkylbenzimidazolium derivatives towards Pheretima posthuma and A549 cell lines and certain descriptors (LUMO of anions and $c_{-}$FPSA of cations), the authors supposed that the presence of $\mathrm{OH}$ (as a counter anion) increases the polar surface area of the cationic head, which leads to higher toxicity (Ranjan et al., 2018c).

\subsection{Other theoretical molecular descriptors}

Theoretical molecular descriptors are most frequently applied. Multiple linear regression (MLR) and non-linear models were obtained for 227 ILs (Fatemi and Izadiyan, 2011) by applying the multilayer perceptron neural network (MLP NN), MLR methods, genetic algorithm approach (GA). Four of the five descriptors applied in the linear model ( $R$ matrix average row sum, $R$ maximal autocorrelation of lag 1/unweighted heavy atom count, topological charge index of order 8 , Kier symmetry index) are associated with the cationic part of ILs. In case of anions, the authors used the HAC descriptor, which correlated with the number of heavy atoms (for instance fluorine atoms) in the anion. The order of significance of applied molecular descriptors is as follows:

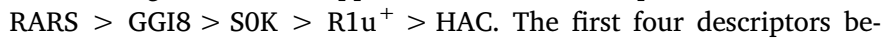
long to the topological descriptor and GETAWAY classes and demonstrate the importance of cationic substituents on cytotoxicity of ILs. According to models, authors concluded that an increase of the number of heavy atoms in the anion leads to an increase of toxicity of ILs.

In another study several predictive models (Cho et al., 2013) were built for cytotoxicity of ILs towards different species using the excess molar refraction; dipolarity/polarizability, hydrogen-bonding acidity, hydrogen-bonding basicity and McGowan volume as descriptors. Using the excess molar refraction; dipolarity/polarizability, hydrogenbonding acidity, hydrogen-bonding basicity and McGowan volume as descriptors, several predictive models were built for cytotoxicity of ILs towards the cell line IPC-81 ( $R^{2}$ of 0.778 , SE of $0.450 \log$ units), the bacterium $V$. fischeri $\left(R^{2}\right.$ of 0.762$)$ and the algae Scenedesmus vacuolatus $\left(R^{2}\right.$ of 0.776$)$. According to analysis of descriptor sensitivity, the McGowan volume was determined as the most important predictor of cytotoxicity in terms of the cation nature. 
Strategy to obtaining environmentally

friendly "green" ionic liquids

\begin{tabular}{|c|c|}
\hline Hazardous Ionic liquids & Green Ionic liquids \\
\hline $\begin{array}{l}\text { CATION } \\
\text { - phosphonium and imidazolium ILs; } \\
\text { branched cation; positively charge } \\
\text { atoms and N-atoms in the cations } \\
\text { ANION } \\
\text { - fluorine-containing ILs, } \\
\text { hydrophobic anions }\end{array}$ & $\begin{array}{l}\text { CATION } \\
\text { - pyridinium and morpholinium ILs } \\
\text { with short polar linear alkyl chains } \\
\text { ANION } \\
\text { - alkyl sulphates and organic anions } \\
\text { Substituent } \\
\cdot \quad \text { short polar linear alkyl chains }\end{array}$ \\
\hline $\begin{array}{l}\text { Substituent } \\
\text { - long hydrophobic alkyl chains }\end{array}$ & \\
\hline
\end{tabular}

Fig. 2. Overview of the role of different factors affecting the toxicity of ILs according to the state of the art of the published models.

Predictive classification and regression models were developed by Roy et al. (Roy and Das, 2013) for the toxicity assessment $\left(\mathrm{LC}_{50}\right)$ of 62 ILs towards D. magna using an extended topochemical atom (ETA) and other two-dimensional topological and constitutional descriptors. The authors proposed that in order to reduce toxicity of ILs, one must design ILs with lower electronegativity and lipophilicity. Electronegativity can be decreased by minimizing the presence of heteroatoms and unsaturated carbon-heteroatom and heteroatom-heteroatom bonds. Reducing the chain length of the cationic head groups can decrease lipophilicity of ILs. The same authors (Bruzzone et al., 2011) carried out another study on the same data set. A previously reported MLR model was outperformed by the best PLS model. Authors demonstrated that by avoiding the aromaticity, nitrogen atoms and increasing branching in the cationic structure might be the key factor in obtaining more lipophilic ILs with reduced toxicity. According to models developed by Izadiyan (Izadiyan et al., 2013), ecotoxicity of ILs is highly related to their chemical structure and especially to the special fragments on the cation skeleton. Moreover, the authors elaborated a practical toxicity classification model of ILs toxicity by applying cluster and principal component analysis (PCA). The toxicity data of 40 ILs towards $S$. vacuolatus were obtained from the UFT/Merck database (UFT Merck Ionic Liquids Biological Effects Database and (n.d.), 2019). Most of 40 ILs were split in three separate clusters according to their structural similarities and level of toxicity based on the covariance matrix.

The network-like similarity graph (NSG) approach was combined with the classification and regression tree (CART) classifier (CruzMonteagudo and Cordeiro, 2014) to find the relevant structure-toxicity relationship trends in case of activity of $281 \mathrm{ILs}$ with respect to cell line IPC-81. The obtained results assembled from both quantitative (CART) and qualitative (NSG) approaches helped to design a combinatorial library of about 700,000 ILs with $80 \%$ accuracy to exhibit an acceptable hazard profile of ILs. This library can play important role for development of ILs for desirable technical applications as a decision-making element.

ETA indices, atom-type fragment descriptors and other categories of chemical descriptors were applied to develop prognostic classification and regression models of toxicity of 60 ILs toward $S$. vacuolatus (Das and Roy, 2014). Research activities were carried out with reference to OECD guidelines for QSAR modeling. The authors proposed that reducing the chain length of cationic substituents and increasing hydrogen bond donor features in cations can lead to a decrease of ecotoxicity of ILs. Furthermore, unsaturated anions in ILs are more toxic than bulky anions with a simple saturated moiety with less lipophilic heteroatoms.

Within a study of Zhao (Zhao et al., 2014), a comprehensive database on toxicity of ILs with over $4000 \mathrm{EC}_{50}$ values was collected. QSAR models (M12, Table 2) were derived by incorporating support vector machine (SVM) and MLR methods. The authors (Zhao et al., 2014) showed that toxicity of ILs can be decreased by increasing the relative number of $\mathrm{O}$ atoms in the molecules. In this work, a nonlinear SVM model performed better in the prediction of toxicity of ILs compared to
MLR ( $\mathrm{R}^{2}$ for MLR and SVM models was 0.892 and 0.958 , respectively). Hydrophobicity is known to significantly affect toxicity of ILs, thus the Ferreira-Kiralj hydrophobicity parameter was suggested (de Melo, 2015) as a constitutional descriptor for modeling toxicity endpoints of ILs. The model with the Ferreira-Kiralj parameter gives a correlation coefficient 0.809 and proves correctness of suggestion. In research devoted to investigation of cytotoxicity of 14 imidazolium-based ILs towards Channel Catfish Ovary cell line, the role of the shape of cationic head groups, length of alkyl substituents, and hydrophobicity was pointed out (Cvjetko Bubalo et al., 2015). The developed LDA (linear discriminant analysis) and MLR models were characterized by a high $R^{2}$ value of 0.961. A nonlinear QSAR model of toxicity of 198 ILs towards cell line IPC-81 was constructed with the cascade correlation network (CCN), probabilistic neural network (PNN), and generalized regression neural networks approaches (Gupta et al., 2015). The generated model allows one to predict discrimination of ILs into four categories of cytotoxicity with an accuracy higher than $86 \%$ and performed correlation with regression models with $R^{2}$ over 0.9 .

Ecotoxicity of ILs towards $V$. fischeri was predicted by applying the genetic function approximation and least squares support vector machine methods (LSSVM) with $R^{2} 0.903$ and 0.933 , respectively (Ma et al., 2015). With respect to the used five descriptors for the cation and one for the anion, the authors suggested that ecotoxicity of ILs mainly depends on the size, lipophilicity, and 3D structure of cations and concluded that the anionic parameters have little influence on ecotoxicity.

Another QSAR study on toxicity of 157 ILs towards V. fischeri was performed using a topological method (Yan et al., 2015). MLR models were developed by combining the topological index, a character vector of atoms, and a distance matrix for atom positions as descriptors $\left(\mathrm{R}^{2}=0.908\right)$.

In the work (Das et al., 2015b), classification and regression-based models were developed with two-dimensional topological descriptors for a dataset of 289 ILs. Linear discriminant analysis (LDA) and PLS (partial least squares regression) models of cytotoxicity $\left(\mathrm{EC}_{50}\right.$ ) values towards rat cell line IPC-81 were designed. The obtained models were in agreement with previously reported models (Bruzzone et al., 2011).

Classification and regression QSAR models with good predictive power with accuracy over $88 \%$ and a coefficient $Q^{2}$ 0.77-0.92 were designed (Hodyna et al., 2016a). The obtained model of antibacterial activity of imidazolium-based ILs was stored in the OCHEM database (www.ochem.eu) and assisted in searching for new potential antimicrobial agents against $B$. subtilis and Ps. aeruginosa.

Linear free energy relationship (LFER) descriptors were applied to obtain six prediction models of toxicity of ILs to two bacteria and a fungus (Cho et al., 2016a). The authors considered the following parameters of ILs as factors modifying their toxicity: molar refraction, dipolarity/polarizability, H-bonding acidity, H-bonding basicity, McGowan volume, cationic interaction, and anionic interaction. The chosen species had different sensitivity to the considered characteristics. For instance, the molecular volume of the cation was a more 


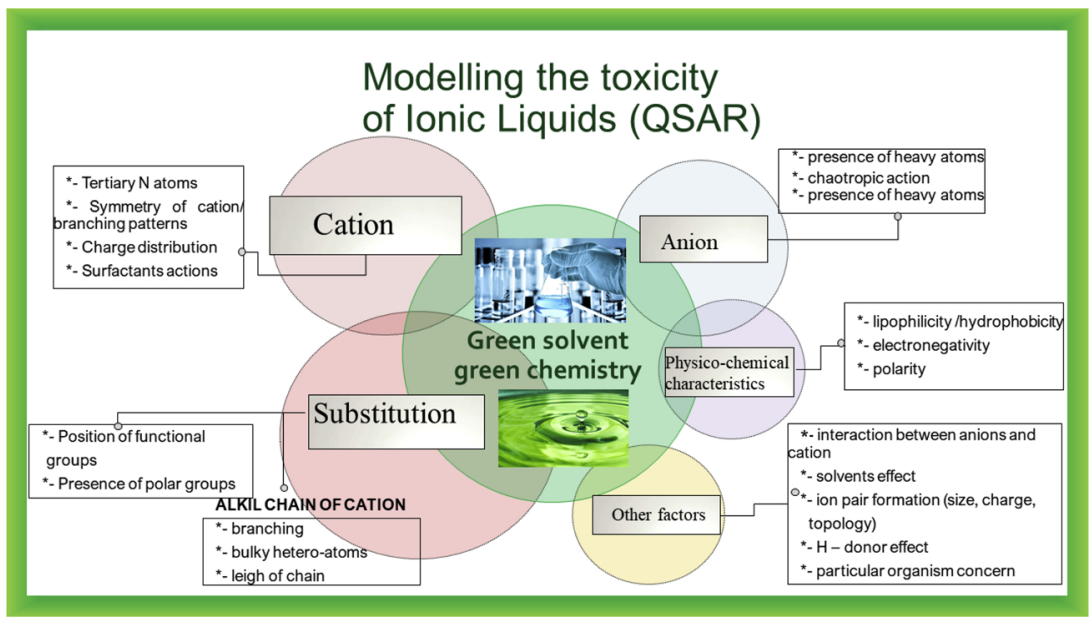

Fig. 3. Generalization of the role of different factors in affecting the toxicity of ILs based on the state-of-the-art of the published models.

critical parameter for $E$. coli and $S$. aureus, whereas dipole interactions and H-bonding basicity of a cation was more influential for $C$. albicans.

QSAR modeling was done with the purpose to access the possibility of application of imidazolium ILs as potential anti-candida inhibitors (Hodyna et al., 2016b). Modeling was performed on the toxicity dataset (MIC) of 88 1,3-dialkylimidazolium ILs towards C. albicans strains with a wide range of toxicity endpoints (from 0.01 to $8,600 \mu \mathrm{g} / \mathrm{mL}$ ). The authors used the following machine-learning methods: the WEKA-RF method for creating classification models; Associative Neural Network (ASNN) and k-Nearest Neighbor Method (k-NN) for generation of the regression models. The 5-fold cross-validation method was applied for internal validation.

In another study (Grzonkowska et al., 2016), a QSAR model was developed by using MLR. According to the published model of the toxicity of ILs towards $V$. fischeri, the toxic effect of ILs can be reduced by introducing a polar group in the cation. The authors showed that toxicity of ILs mainly depends on the cation properties, namely, the size and length of the substituent group.

In another study, the authors (Cho et al., 2016b) applied unified descriptors to predict toxicological effects of ILs towards 58 different biological systems. A model with LFER descriptors was proposed for 250 cations and 60 anions. The sensitivity of each biological system was estimated based on the obtained models.

The predictive ability of local vs. global QSAR models was compared by Sosnowska (Sosnowska et al., 2017) for predicting ILs toxicity (EC ${ }_{50}$ ) against IPC-81 cell line. 304 experimental data points were accumulated from literature for 10 groups of ILs according to the IL cation type. Both internal and external validation was performed. The authors recommended using the global model in practice instead of local models.

MLR models with matrix norm indexes were built to predict toxicity of 169 and 101 ILs with minimal inhibitory concentration (MICs) and minimal bactericidal concentration (MBCs), respectively, against $S$. aureus. Two QSAR models were developed with a correlation coefficient $\left(R^{2}\right) 0.919$ and standard error of estimate (SE) 0.341 for MIC, and $R^{2} 0.913$ and $S E 0.282$ for MBC. Both external and internal validation indicated a good predictability of the model.

Combined work (Ben Ghanem et al., 2018) was done by generating effect data [50 \% effective concentration - $\mathrm{EC}_{50}$ ] and modeling toxicity of 52 ILs towards Aeromonas hydrophila featuring 4 different cations and 11 anions. The obtained QSAR models indicated that toxicity of ILs depends strongly on the presence of a hydrophobic anion such as bis ((trifluoromethyl)sulfonyl)imide and the length of the cation substituents. The k-fold cross-validation was carried out for reliability evaluation. The obtained QSAR model was found to have a high value of the correlation coefficient $R^{2} 0.904$ and a small mean square error
0.095 .

Combination of QSAR methods and molecular docking was used to obtain several classification and regression models for 131 imidazolium ILs (Hodyna et al., 2018). Comparative analysis of the models showed the advantage of regression models for analysis of ILs activity. Several models were constructed with various descriptors such as E-State indices, ALogPS, Chemaxon descriptors, inductive descriptors. The developed models are available in the OCHEM database (Sushko et al,, 2011).

Predictive QSAR modeling studies were carried out by Luis (Luis et al., 2010a). MLR models with group contribution descriptors were developed based on $V$. fischeri toxicity data $\left(\mathrm{EC}_{50}\right)$ for 75 ILs: 9 cations and 17 anions. The lowest aquatic toxicity was found for the imidazolium cation and p-toluenesulfonate and $\mathrm{N}\left(\mathrm{CF}_{3}\right)_{2}$ anions. Free GRid-INdependent descriptors (GRINDs) were applied to design citotoxicity models of 296 ILs towards cell line IPC-81 (Farahani et al., 2018). Descriptors were derived from GRid molecular interaction fields. Data of citotoxicity for data sets were obtained from UFT/Merck database (UFT Merck Ionic Liquids Biological Effects Database and (n.d.), 2019).

Modeling on experimental data was performed for 28 ILs based on the following descriptors: rotatable bond number (RBN), mean atomic van der Waals volume (Mv) and interaction of second power carbon numbers with the molar ratio of hydrogen-bond acceptor to hydrogenbond donor (Ahmadi et al., 2018) (HBA and HBD). Authors demonstrated that RBN and Mv of HBD compounds showed positive effects on cytotoxicity of tested ILs, then the molar ratio of HBA to HBD and the number of HBD carbons exhibited the negative impact on activity of ILs. Models of minimal inhibitory concentration (Holovchenko et al., 2018) were developed based on data for 242 ILs from the OCHEM database (Sushko et al., 2011). According to the predictions obtained, the authors (Holovchenko et al., 2018) supposed that 1,3-oxazol-4-yl(triphenyl)phosphonium derivatives have antibacterial activities. Substances of interest were synthesized and screened for their antibacterial activity towards Staphylococcus aureus ATCC 25923 and Staphylococcus. According to performed antibacterial tests all compounds demonstrated the expected activity towards bacteria (Holovchenko et al., 2018).

\subsection{Influence of physicochemical properties}

The relationship between structural physicochemical properties of ILs and their aquatic toxicity was investigated by Paternò et al. (Paternò et al. (2016a)). The authors applied the in-silico approach VolSurf + to design a PLS model for a dataset of 128 cations and 48 anions. In this method, the information is presented as 3D GRID molecular interaction fields (MIFs). Most of the authors suggest to design descriptors separately for anions and cations. There are only several publications (Roy 


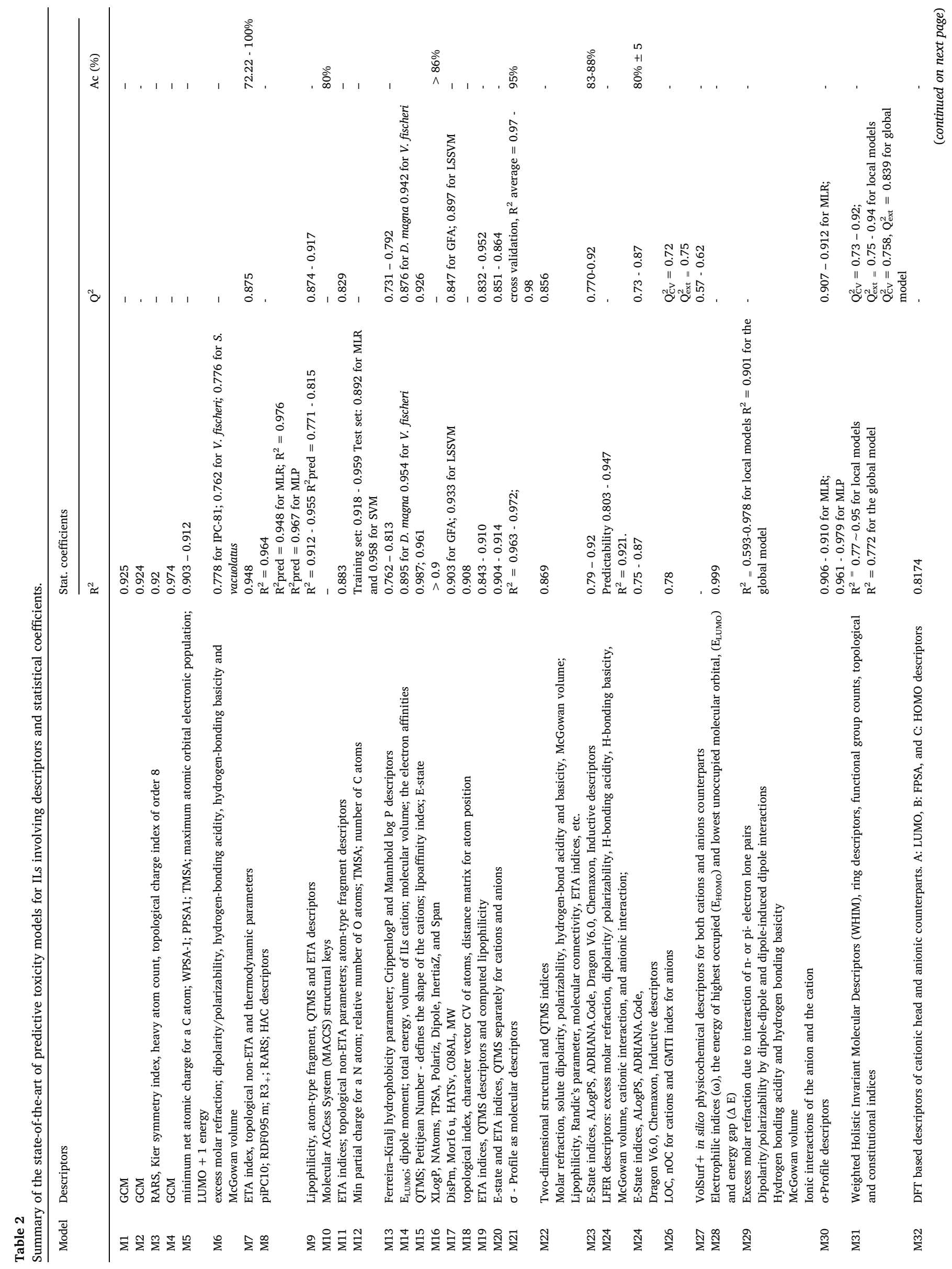


et al., 2014; Rybinska et al., 2016) which consider cation-anion interactions in their models. However, in their final discussion and conclusion, interactions between the ions has not received significant attention. Most of the researches point to the leading role of the cation and its substituents in ILs toxicity. Besides the structure of ILs, other factors can influence their toxicity. It was shown (Pieraccini et al., 2007) that the toxicity of ILs towards algae is reduced in saline water. The choice of the type of organisms is also essential for determining and modeling the ILs toxicity.

\subsection{Quantitative structure-toxicity-toxicity relationship models}

Quantitative structure-toxicity-toxicity relationship (QSTTR) models perform interspecies correlation between simple and more complicated species. Different groups of organisms can differently respond to the ILs, but species of the same family may identically respond to the chemicals, whereas species from close families responded the same way with a different degree. Such research is aimed to find out the interconnection for different species. QSTTR model was successfully used to interconnect toxicity of substances for two or more closely related species. For QTTR models, it is typical when available experimental toxicity data for one species are use as independent variables for prediction of toxicity of the ILs for another species. For example, QTTR was employed by Das (Das et al., 2015a) for extrapolating toxicity of ILs towards $V$. fischeri and D. magna. An external data set of toxicity of 302 ILs towards bacterium ( $V$. fischeri) was used to develop the model of toxicity of these ILs towards a cladoceran (D. magna) and green algae (S. vacuolatus). It was found that the contribution of the cation into toxicity of ILs was more prominent than that of the anions.

Another predictive interspecies QTTR model was obtained to interlink algae toxicity of ILs with toxicity (Roy et al., 2015b). Primarily the authors developed a PLS model of toxicity of 41 ILs towards $S$. vacuolatus using E-state indices and extended topochemical atom (ETA) indices calculated separately for cations and anions. Computational QTTR models (Barycki et al., 2018) were obtained for the entire set of 64 ILs based on two different experiments (Kumar et al., 2009; Wang et al., 2007) with different cell lines (with only two ILs being the same in different data series). By applying theoretical molecular descriptors and two approaches for feature selection (classical GA and its modified version -Multi-Objective Genetic Algorithm (MOGA)), researchers (Barycki et al., 2018) obtained the model with $\mathrm{R}^{2}$ values of 0.82-0.96.

\section{Discussion}

In summary, analysis of existing predictive QSAR toxicity models and biodegradation of ILs assists in better interpretation of mechanisms underlying their toxicity and behavior in environment. In general, toxicity of ILs depends on both ions (cation and anion) as well as on their interaction. In the published models, it was established that toxicity of ILs mainly depends on the nature of the cation and increases with the cation alkyl chain length (Montalbán et al., 2016; Izadiyan et al., 2013), whereas the anion exerts in general a more limited impact on the overall toxicity (Egorova and Ananikov, 2014; Luis et al., 2010a; Ventura et al., 2012; Grzonkowska et al., 2016). The important role of the alkyl chain length in the cation in the contribution to ecotoxicity of ILs is in good agreement with literature data (Luis et al., 2007; Ranke et al., 2004, 2007a).

The effect of the anion, cation core, and presence of functionalized groups in the cation chain on toxicity of ILs is less important as compared to the alkyl chain length in the cation substituent (Grzonkowska et al., 2016; Montalbán et al., 2016). According to the literature (Arning et al., 2008; Docherty and Kulpa, 2005; Ranke et al., 2004, 2007a), ILs with the same cation and different anions do not show any statistical difference in toxicity. With respect to the cation structure, it was proven that more branched cations with long alkyl chains are more toxic than smaller ILs with linear alkyl chains (Grzonkowska et al., 2016). Toxicity 
of ILs is reduced by the presence of a polar group in the cation substituent chain.

Toxicity of ILs is moreover strongly correlated with their lipophilicity (Ben Ghanem et al., 2015b; Rybinska et al., 2016) since the hydrophobic character of ILs allows them to be easily incorporated into biological membranes (Luis et al., 2010a; Izadiyan et al., 2013). Some key properties such as molecular size, branching, presence of hydroxyl groups (making a molecule hydrophilic), induce lipophilicity of ILs and govern their toxicity. As discussed above, the nature of the cation and substituent are vital for the interaction of ILs with cells and biotic species, as determined by lipophilicity, hydrogen bonding capacity, electronegativity, and size of ILs. A summary of the different factors that affect the toxicity of ILs is schematically given in Fig. 3. This overview is of broad interest as it not only provides useful information about the structural patterns of ILs responsible for toxicity and biodegradation of ILs, but also by shedding light on selecting and designing greener ILs based on published QSAR models.

\section{Conclusions}

In this contribution, we presented the current state of the art in the area of design of computational models of ILs toxicity towards different species and cell lines. A general overview of the database and datasets used in QSAR studies for ILs toxicity modeling is given. With respect to the published models, it was concluded that toxicity of ILs mainly depends on the cation and increases with the cation alkyl chain length and for the more branched cation chain groups. With the knowledge of the structures that are responsible for the toxicity of ILs, it is possible to control toxicity of chemicals. In case of ILs, it is reasonable to synthesize a morpholinium head group as it shows the least toxicity towards several test subjects (Stolte et al., 2007). The overview shows that the presence of a polar group like e.g. hydroxyl or nitrile groups in the cationic substituent chain reduces the toxicity and increases the efficiency of biodegradation. The same tendency was observed for short polar side-chains linked to the cations of ILs. Meanwhile the effect of the anion was shown to play mostly an insignificant role in toxicity of ILs. Thereby from a toxicological point of view it is clear that in order to obtain eco-friendly ILs one needs to use morpholinium or pyridinium cations with short linear and polar alkyl chains and avoid fluorinecontaining and hydrophobic anions with cations containing positively charged atoms and $\mathrm{N}$ atoms. As mentioned above, the ILs structure is essential for their interaction with cell membranes. The cell membrane in general has a total negative charge and thereby ILs with nucleophilic properties have a higher tendency to interact with biomembranes.

Development of reliable QSAR/QSTR models of toxicity of ILs is essential for reducing the time and cost of experimental research and thus can lead to understanding the strategy in synthesis of green ILs. Even considering the promising benefit from QSAR models for ILs toxicity, most of the publications on this topic used a limited number of test species and only several ILs. To evaluate the total assessment of ILs for regulatory purposes, it is important to expand the number of species and ILs. The information about the state of ILs during the experiments is limited. It will be a good practice to look over the ILs state under experimental conditions. Meanwhile, linking the structure of ILs to their environmental behavior and degradation is of great interest. Such research will provide further understanding of the mechanisms of toxicity and biodegradation of ILs.

Analysis of descriptors discussed in published QSAR studies assists in providing a proper interpretation of possible mechanisms of ILs toxicity on the basis of the structures that mainly drive adverse effects. Thus, this brief overview of modeling studies related to toxicity prediction of ionic liquids manifests applicability of a number of different models allowing for achieving high correlation coefficients. Researchers recommend considering the structure of the cation and the anion separately. Most of the studies so far are based on a variety of modeling techniques such as regression (MLR, EVM, PLS), SVM, ANN, GPA, GCM, and LFER approaches. To have better understanding of the IL structure - toxicity relationship is important for known and new emerging ILs.

\section{Declaration of Competing Interest}

The authors have no competing interests to report

\section{Acknowledgements}

LMK and NBA kindly acknowledge the financial support of the Ministry of Science and Higher Education of the Russian Federation in the framework of the Increase Competitiveness Program of NUST «MISiS» (No. K2-2019-005).

\section{References}

Ahmadi, R., Hemmateenejad, B., Safavi, A., Shojaeifard, Z., Mohabbati, M., Firuzi, O., 2018. Assessment of cytotoxicity of choline chloride-based natural deep eutectic solvents against human HEK-293 cells: a QSAR analysis. Chemosphere. 209, 831-838. https://doi.org/10.1016/j.chemosphere.2018.06.103.

Alberto, E.E., Rossato, L.L., Alves, S.H., Alves, D., Braga, A.L., 2011. Imidazolium ionic liquids containing selenium: synthesis and antimicrobial activity. Org. Biomol. Chem. 9, 1001-1003. https://doi.org/10.1039/C0OB01010C.

Alvarez-Guerra, M., Irabien, A., 2011. Design of ionic liquids: an ecotoxicity (Vibrio fischeri) discrimination approach. Green Chem. 13, 1507. https://doi.org/10.1039/ c0gc00921k.

Andrew, A., Wells, S., Coombe, V.T., 2006. On the Freshwater Ecotoxicity and Biodegradation Properties of Some Common Ionic Liquids. https://doi.org/10.1021/ OP060048I.

Arning, J., Stolte, S., Böschen, A., Stock, F., Pitner, W.-R., Welz-Biermann, U., Jastorff, B., Ranke, J., 2008. Qualitative and quantitative structure activity relationships for the inhibitory effects of cationic head groups, functionalised side chains and anions of ionic liquids on acetylcholinesterase. Green Chem. 10, 47-58. https://doi.org/10. 1039/B712109A.

Awad, W.H., Gilman, J.W., Nyden, M., Harris, R.H., Sutto, T.E., Callahan, J., Trulove, P.C., DeLong, H.C., Fox, D.M., 2004. Thermal degradation studies of alkyl-imidazolium salts and their application in nanocomposites. Thermochim. Acta 409, 3-11. https://doi.org/10.1016/S0040-6031(03)00334-4.

Baker, T.J., Tyler, C.R., Galloway, T.S., 2014. Impacts of metal and metal oxide nanoparticles on marine organisms. Environ. Pollut. 186, 257-271. https://doi.org/10. 1016/j.envpol.2013.11.014.

Barycki, M., Sosnowska, A., Jagiello, K., Puzyn, T., 2018. Multi-objective genetic algorithm (MOGA) As a feature selecting strategy in the development of ionic liquids' quantitative toxicity-Toxicity relationship models. J. Chem. Inf. Model. 58, 2467-2476. https://doi.org/10.1021/acs.jcim.8b00378.

Barycki, M., Sosnowska, A., Puzyn, T., 2017. Which structural features stand behind micelization of ionic liquids? Quantitative Structure-Property Relationship studies. J. Colloid Interface Sci. 487, 475-483. https://doi.org/10.1016/j.jcis.2016.10.066.

Basant, N., Gupta, S., Singh, K.P., 2015. Predicting acetyl cholinesterase enzyme inhibition potential of ionic liquids using machine learning approaches: an aid to green chemicals designing. J. Mol. Liq. 209, 404-412. https://doi.org/10.1016/J.MOLLIQ. 2015.06.001.

Ben Ghanem, O., Mutalib, M.I.A., Leveque, J.M., El-Harbawi, M., 2017. Development of QSAR model to predict the ecotoxicity of Vibrio fischeri using COSMO-RS descriptors. Chemosphere. 170, 242-250. https://doi.org/10.1016/j.chemosphere.2016.12.003.

Ben Ghanem, O., Shah, S.N., Lévêque, J.-M., Mutalib, M.I.A., El-Harbawi, M., Khan, A.S., Alnarabiji, M.S., Al-Absi, H.R.H., Ullah, Z., 2018. Study of the antimicrobial activity of cyclic cation-based ionic liquids via experimental and group contribution QSAR model. Chemosphere. 195, 21-28. https://doi.org/10.1016/j.chemosphere.2017.12. 018.

Ben Ghanem, O., Papaiconomou, N., Abdul Mutalib, M.I., Viboud, S., El-Harbawi, M., Uemura, Y., Gonfa, G., Azmi Bustam, M., Lévêque, J.-M., 2015a. Thermophysical properties and acute toxicity towards green algae and Vibrio fischeri of amino acidbased ionic liquids. J. Mol. Liq. 212, 352-359. https://doi.org/10.1016/J.MOLLIQ. 2015.09.017.

Ben Ghanem, O., Mutalib, M.I.A., El-Harbawi, M., Gonfa, G., Kait, C.F., Alitheen, N.B.M., L??v??que, J.M., 2015b. Effect of imidazolium-based ionic liquids on bacterial growth inhibition investigated via experimental and QSAR modelling studies. J. Hazard. Mater. 297, 198-206. https://doi.org/10.1016/j.jhazmat.2015.04.082.

Bernot, R.J., Brueseke, M.A., Evans-White, M.A., Lamberti, G.A., 2005. Acute and chronic toxicity of imidazolium-based ionic liquids on Daphnia magna. Environ. Toxicol. Chem. 24, 87-92. (Accessed 18 July 2018). http://www.ncbi.nlm.nih.gov/pubmed/ 15683171.

Borowiecki, P., Milner-Krawczyk, M., Brzezińska, D., Wielechowska, M., Plenkiewicz, J., 2013. Synthesis and antimicrobial activity of imidazolium and triazolium chiral ionic liquids. European J. Org. Chem. 2013, 712-720. https://doi.org/10.1002/ejoc. 201201245.

Bruzzone, S., Chiappe, C., Focardi, S.E., Pretti, C., Renzi, M., 2011. Theoretical descriptor for the correlation of aquatic toxicity of ionic liquids by quantitative structure-toxicity relationships. Chem. Eng. J. 175, 17-23. https://doi.org/10.1016/j.cej.2011.08. 073. 
Cao, L., Zhu, P., Zhao, Y., Zhao, J., 2018. Using machine learning and quantum chemistry descriptors to predict the toxicity of ionic liquids. J. Hazard. Mater. 352, 17-26. https://doi.org/10.1016/j.jhazmat.2018.03.025.

Carson, L., Chau, P.K.W., Earle, M.J., Gilea, M.A., Gilmore, B.F., Gorman, S.P., McCann, M.T., Seddon, K.R., 2009. Antibiofilm activities of 1-alkyl-3-methylimidazolium chloride ionic liquids. Green Chem. 11, 492. https://doi.org/10.1039/b821842k.

Cho, C.-W., Yun, Y.-S., 2016. Interpretation of toxicological activity of ionic liquids to acetylcholinesterase inhibition via in silico modelling. Chemosphere. 159, 178-183. https://doi.org/10.1016/j.chemosphere.2016.06.005.

Cho, C.-W., Ranke, J., Arning, J., Thöming, J., Preiss, U., Jungnickel, C., Diedenhofen, M., Krossing, I., Stolte, S., 2013. In silico modelling for predicting the cationic hydrophobicity and cytotoxicity of ionic liquids towards the Leukemia rat cell line, Vibrio fischeri and Scenedesmus vacuolatus based on molecular interaction potentials of ions. SAR QSAR Environ. Res. 24, 863-882. https://doi.org/10.1080/1062936X. 2013.821092.

Cho, C.W., Park, J.S., Stolte, S., Yun, Y.S., 2016a. Modelling for antimicrobial activities of ionic liquids towards Escherichia coli, Staphylococcus aureus and Candida albicans using linear free energy relationship descriptors. J. Hazard. Mater. 311, 168-175. https://doi.org/10.1016/j.jhazmat.2016.03.006.

Cho, C.-W., Stolte, S., Yun, Y.-S., 2016b. Comprehensive approach for predicting toxicological effects of ionic liquids on several biological systems using unified descriptors. Sci. Rep. 6, 33403. https://doi.org/10.1038/srep33403.

Cieniecka-Rosłonkiewicz, A., Pernak, J., Kubis-Feder, J., Ramani, A., Robertson, A.J., Seddon, K.R., 2005. Synthesis, anti-microbial activities and anti-electrostatic properties of phosphonium-based ionic liquids. Green Chem. 7, 855. https://doi.org/10. 1039/b508499g.

Coleman, D., Gathergood, N., 2010. Biodegradation studies of ionic liquids. Chem. Soc Rev. 39, 600. https://doi.org/10.1039/b817717c.

Cornellas, A., Perez, L., Comelles, F., Ribosa, I., Manresa, A., Garcia, M.T., 2011. Selfaggregation and antimicrobial activity of imidazolium and pyridinium based ionic liquids in aqueous solution. J. Colloid Interface Sci. 355, 164-171. https://doi.org/ 10.1016/j.jcis.2010.11.063.

Cornmell, R.J., Winder, C.L., Tiddy, G.J.T., Goodacre, R., Stephens, G., 2008. Accumulation of ionic liquids in Escherichia coli cells. Green Chem. 10, 836. https:// doi.org/10.1039/b807214k.

Costa, S.P.F., Justina, V.D., Bica, K., Vasiloiu, M., Pinto, P.C.A.G., Saraiva, M.L.M.F.S., 2014. Automated evaluation of pharmaceutically active ionic liquids' (eco)toxicity through the inhibition of human carboxylesterase and Vibrio fischeri. J. Hazard. Mater. 265, 133-141. https://doi.org/10.1016/j.jhazmat.2013.11.052.

Couling, D.J., Bernot, R.J., Docherty, K.M., Dixon, J.K., Maginn, E.J., 2006. Assessing the factors responsible for ionic liquid toxicity to aquatic organisms via quantitative structure-property relationship modeling. Green Chem. 8, 82-90. https://doi.org/10. 1039/B511333D.

Cruz-Monteagudo, M., Cordeiro, M.N.D.S., 2014. Chemoinformatics Profiling of Ionic Liquids-Uncovering Structure-Cytotoxicity Relationships With Network-like Similarity Graphs. Toxicol. Sci. 138, 191-204. https://doi.org/10.1093/toxsci/ kft210.

Cvjetko Bubalo, M., Radošević, K., Radojčić Redovniković, I., Halambek, J., Gaurina Srček, V., 2014. A brief overview of the potential environmental hazards of ionic liquids. Ecotoxicol. Environ. Saf. 99, 1-12. https://doi.org/10.1016/j.ecoenv.2013. 10.019 .

Cvjetko Bubalo, M., Radošević, K., Gaurina Srček, V., Das, R.N., Popelier, P., Roy, K., 2015. Cytotoxicity towards CCO cells of imidazolium ionic liquids with functionalized side chains: preliminary QSTR modeling using regression and classification based approaches. Ecotoxicol. Environ. Saf. 112, 22-28. https://doi.org/10.1016/j. ecoenv.2014.10.029.

Cybulski, J., Wiśniewska, A., Kulig-Adamiak, A., Lewicka, L., Cieniecka-Rosłonkiewicz, A., Kita, K., Fojutowski, A., Nawrot, J., Materna, K., Pernak, J., 2008. Long-alkylChain quaternary ammonium lactate based ionic liquids. Chem. - A Eur. J. 14, 9305-9311. https://doi.org/10.1002/chem.200800973.

Das, R.N., Roy, K., 2014. Predictive modeling studies for the ecotoxicity of ionic liquids towards the green algae Scenedesmus vacuolatus. Chemosphere. 104, 170-176. https://doi.org/10.1016/j.chemosphere.2013.11.002.

Das, R.N., Roy, K., 2013. Advances in QSPR/QSTR models of ionic liquids for the design of greener solvents of the future. Mol. Divers. 17, 151-196. https://doi.org/10.1007/ s11030-012-9413-y.

Das, R.N., Roy, K., Popelier, P.L.A., 2015a. Interspecies quantitative structure-toxicitytoxicity (QSTTR) relationship modeling of ionic liquids. Toxicity of ionic liquids to V. fischeri, D. Magna and S. Vacuolatus. Ecotoxicol. Environ. Saf. 122, 497-520. https://doi.org/10.1016/j.ecoenv.2015.09.014.

Das, R.N., Roy, K., Popelier, P.L.A., 2015b. Exploring simple, transparent, interpretable and predictive QSAR models for classification and quantitative prediction of rat toxicity of ionic liquids using OECD recommended guidelines. Chemosphere. 139, 163-173. https://doi.org/10.1016/j.chemosphere.2015.06.022.

de Melo, E.B., 2015. A structure-activity relationship study of the toxicity of ionic liquids using an adapted Ferreira-Kiralj hydrophobicity parameter. Phys. Chem. Chem. Phys. 17, 4516-4523. https://doi.org/10.1039/c4cp04142a.

Dearden, J.C., 2016. The history and development of quantitative structure-activity relationships (QSARs). Int. J. Quant. Struct. Relationships. 1, 1-44. https://doi.org/10. 4018/IJQSPR.2016010101.

Demberelnyamba, D., Kim, K.-S., Choi, S., Park, S.-Y., Lee, H., Kim, C.-J., Yoo, I.-D., 2004. Synthesis and antimicrobial properties of imidazolium and pyrrolidinonium salts. Bioorg. Med. Chem. 12, 853-857. https://doi.org/10.1016/j.bmc.2004.01.003.

Docherty, K.M., Kulpa Jr., C.F., 2005. Toxicity and antimicrobial activity of imidazolium and pyridinium ionic liquids. Green Chem. 7, 185. https://doi.org/10.1039/ b419172b.
Docherty, K.M., Dixon, J.K., Kulpa Jr, C.F., 2007. Biodegradability of imidazolium and pyridinium ionic liquids by an activated sludge microbial community. Biodegradation. 18, 481-493. https://doi.org/10.1007/s10532-006-9081-7.

Dong, Q., Muzny, C.D., Kazakov, A., Diky, V., Magee, J.W., Widegren, J.A., Chirico, R.D., Marsh, K.N., Frenkel, M., Thermo, I.L., 2007. A Free-Access Web Database for Thermodynamic Properties of Ionic Liquidst. https://doi.org/10.1021/JE700171F.

Egorova, K.S., Ananikov, V.P., 2014. Toxicity of ionic liquids: eco(cyto)activity as complicated, but unavoidable parameter for task-specific optimization. ChemSusChem. 7, 336-360. https://doi.org/10.1002/cssc.201300459.

Farahani, S.R., Sohrabi, M.R., Ghasemi, J.B., 2018. A detailed structural study of cytotoxicity effect of ionic liquids on the leukemia rat cell line IPC-81 by three dimensional quantitative structure toxicity relationship. Ecotoxicol. Environ. Saf. 158, 256-265. https://doi.org/10.1016/j.ecoenv.2018.04.040.

Fatemi, M.H., Izadiyan, P., 2011. Cytotoxicity estimation of ionic liquids based on their effective structural features. Chemosphere. 84, 553-563. https://doi.org/10.1016/j. chemosphere.2011.04.021.

Fei, Z., Geldbach, T.J., Zhao, D., Dyson, P.J., 2006. From dysfunction to bis-function: on the design and applications of functionalised ionic liquids. Chem. - A Eur. J. 12, 2122-2130. https://doi.org/10.1002/chem.200500581.

Garcia, M.T., Gathergood, N., Scammells, P.J., 2005. Biodegradable ionic liquids : part II. Effect of the anion and toxicology. Green Chem. 7, 9. https://doi.org/10.1039/ b411922c.

Garcia, M.T., Ribosa, I., Perez, L., Manresa, A., Comelles, F., 2013. Aggregation behavior and antimicrobial activity of ester-functionalized imidazolium- and pyridinium-based ionic liquids in aqueous solution. Langmuir. 29, 2536-2545. https://doi.org/10. 1021/la304752e.

García, M., Ribosa, I., Guindulain, T., Sánchez-Leal, J., Vives-Rego, J., 2001. Fate and effect of monoalkyl quaternary ammonium surfactants in the aquatic environment. Environ. Pollut. 111, 169-175. https://doi.org/10.1016/S0269-7491(99)00322-X.

Gathergood, N., Scammells, P.J., Garcia, M.T., 2006. Biodegradable ionic liquids: part III. The first readily biodegradable ionic liquids. Green Chem. 8, 156. https://doi.org/10. 1039/b516206h.

Gilmore, B.F., Andrews, G.P., Borberly, G., Earle, M.J., Gilea, M.A., Gorman, S.P., Lowry, A.F., McLaughlin, M., Seddon, K.R., 2013. Enhanced antimicrobial activities of 1alkyl-3-methyl imidazolium ionic liquids based on silver or copper containing anions. New J. Chem. 37, 873. https://doi.org/10.1039/c3nj40759d.

Grzonkowska, M., Sosnowska, A., Barycki, M., Rybinska, A., Puzyn, T., 2016. How the structure of ionic liquid affects its toxicity to Vibrio fischeri? Chemosphere. 159, 199-207. https://doi.org/10.1016/j.chemosphere.2016.06.004.

Gupta, S., Basant, N., Singh, K.P., 2015. Nonlinear QSAR modeling for predicting cytotoxicity of ionic liquids in leukemia rat cell line: an aid to green chemicals designing. Environ. Sci. Pollut. Res. 22, 12699-12710. https://doi.org/10.1007/s11356-0154526-3.

Hajfarajollah, H., Mokhtarani, B., Noghabi, K.A., Sharifi, A., Mirzaei, M., 2014 Antibacterial and antiadhesive properties of butyl-methylimidazolium ionic liquids toward pathogenic bacteria. RSC Adv. 4, 42751-42757. https://doi.org/10.1039/ C4RA07055K.

He, W., Yan, F., Jia, Q., Xia, S., Wang, Q., 2018. OSAR models for describing the toxicological eff ;ects of ILs against Staphylococcus aureus based on norm indexes. Chemosphere. 195, 831-838. https://doi.org/10.1016/j.chemosphere.2017.12.091.

Hernández-Fernández, F.J., Bayo, J., Pérez de los Ríos, A., Vicente, M.A., Bernal, F.J., Quesada-Medina, J., 2015. Discovering less toxic ionic liquids by using the Microtox toxicity test. Ecotoxicol. Environ. Saf. 116, 29-33. https://doi.org/10.1016/j.ecoenv. 2015.02.034.

Hodyna, D., Kovalishyn, V., Semenyuta, I., Blagodatnyi, V., Rogalsky, S., Metelytsia, L., 2018. Imidazolium ionic liquids as effective antiseptics and disinfectants against drug resistant S. Aureus : in silico and in vitro studies. Comput. Biol. Chem. 73, 127-138. https://doi.org/10.1016/j.compbiolchem.2018.01.012.

Hodyna, D., Kovalishyn, V., Rogalsky, S., Blagodatnyi, V., Petko, K., Metelytsia, L., 2016a. Antibacterial activity of imidazolium-based ionic liquids investigated by QSAR modeling and experimental studies. Chem. Biol. Drug Des. 88, 422-433. https://doi. org $/ 10.1111 /$ cbdd.12770.

Hodyna, D., Kovalishyn, V., Rogalsky, S., Blagodatnyi, V., Metelytsia, L., 2016b. Imidazolium ionic liquids as potential anti-candida inhibitors: QSAR modeling and experimental studies. Curr. Drug Discov. Technol. 13, 109-119. (accessed September 17, 2019). http://www.ncbi.nlm.nih.gov/pubmed/27160290.

Holovchenko, O.V., Kobzar, O.L., Brovarets, V.S., Prokopenko, V.M., Kovalishyn, V., Kalashnikova, L.E., Ocheretniuk, A.D., Trush, M.M., Metelytsia, L.O., New, 1, 2018 3-oxazolylphosphonium salts as potential biocides: QSAR study, synthesis, antibacterial activity and toxicity evaluation. Lett. Drug Des. Discov. 15, 1259-1267. https://doi.org/10.2174/1570180815666180219164334.

Hossain, M.I., El-Harbawi, M., Alitheen, N.B.M., Noaman, Y.A., Lévêque, J.-M., Yin, C.-Y., 2013. Synthesis and anti-microbial potencies of 1-(2-hydroxyethyl)-3-alkylimidazolium chloride ionic liquids: microbial viabilities at different ionic liquids concentrations. Ecotoxicol. Environ. Saf. 87, 65-69. https://doi.org/10.1016/j.ecoenv.2012. 09.020.

Hou, X.-D., Liu, Q.-P., Smith, T.J., Li, N., Zong, M.-H., 2013. Evaluation of toxicity and biodegradability of cholinium amino acids ionic liquids. PLoS One 8, e59145. https://doi.org/10.1371/journal.pone.0059145.

Hough-Troutman, W.L., Smiglak, M., Griffin, S., Matthew Reichert, W., Mirska, I. Jodynis-Liebert, J., Adamska, T., Nawrot, J., Stasiewicz, M., Rogers, R.D., Pernak, J., 2009. Ionic liquids with dual biological function: sweet and anti-microbial, hydrophobic quaternary ammonium-based salts. New J. Chem. 33, 26-33. https://doi.org/ 10.1039/B813213P.

Ismail Hossain, M., Samir, B.B., El-Harbawi, M., Masri, A.N., Abdul Mutalib, M.I., Hefter, G., Yin, C.-Y., 2011. Development of a novel mathematical model using a group 
contribution method for prediction of ionic liquid toxicities. Chemosphere. 85, 990-994. https://doi.org/10.1016/j.chemosphere.2011.06.088.

Izadiyan, P., Fatemi, M.H., Izadiyan, M., 2013. Elicitation of the most important structural properties of ionic liquids affecting ecotoxicity in limnic green algae; a QSAR approach. Ecotoxicol. Environ. Saf. 87, 42-48. https://doi.org/10.1016/j.ecoenv. 2012.10.005.

Jordan, A., Gathergood, N., 2015. Biodegradation of ionic liquids - a critical review. Chem. Soc. Rev. 44, 8200-8237. https://doi.org/10.1039/C5CS00444F.

Karakashev, S.I., Smoukov, S.K., 2017. CMC prediction for ionic surfactants in pure water and aqueous salt solutions based solely on tabulated molecular parameters. J. Colloid Interface Sci. 501, 142-149. https://doi.org/10.1016/J.JCIS.2017.04.046.

Kumar, R.A., Papaïconomou, N., Lee, J.-M., Salminen, J., Clark, D.S., Prausnitz, J.M., 2009. In vitro cytotoxicities of ionic liquids: effect of cation rings, functional groups, and anions. Environ. Toxicol. 24, 388-395. https://doi.org/10.1002/tox.20443.

Latała, A., Nędzi, M., Stepnowski, P., 2009. Toxicity of imidazolium and pyridinium based ionic liquids towards algae. Chlorella vulgaris, Oocystis submarina (green algae) and Cyclotella meneghiniana, Skeletonema marinoi (diatoms). Green Chem. 11, 580. https://doi.org/10.1039/b821140j.

Li, X., Zhao, J., Li, Q., Wang, L., Tsang, S.C., 2007. Ultrasonic chemical oxidative degradations of 1,3-dialkylimidazolium ionic liquids and their mechanistic elucidations. Dalton Trans. 1875-1880. (Accessed 19 July 2018). http://www.ncbi.nlm.nih.gov/ pubmed/17702165.

Liwarska-Bizukojc, E., Maton, C., Stevens, C.V., Gendaszewska, D., 2014. Biodegradability and kinetics of the removal of new peralkylated imidazolium ionic liquids. J. Chem. Technol. Biotechnol. 89, 763-768. https://doi.org/10.1002/jctb. 4187.

Łuczak, J., Jungnickel, C., Łącka, I., Stolte, S., Hupka, J., 2010. Antimicrobial and surface activity of 1-alkyl-3-methylimidazolium derivatives. Green Chem. 12, 593. https:// doi.org/10.1039/b921805j.

Luis, P., Ortiz, I., Aldaco, R., Irabien, A., 2007. A novel group contribution method in the development of a QSAR for predicting the toxicity (Vibrio fischeri EC50) of ionic liquids. Ecotoxicol. Environ. Saf. 67, 423-429. https://doi.org/10.1016/j.ecoenv. 2006.06.010.

Luis, P., Garea, A., Irabien, A., 2010a. Quantitative structure-activity relationships (QSARs) to estimate ionic liquids ecotoxicity EC50 (Vibrio fischeri). J. Mol. Liq. 152, 28-33. https://doi.org/10.1016/J.MOLLIQ.2009.12.008.

Luis, P., Garea, A., Irabien, A., 2010b. Quantitative structure-activity relationships (QSARs) to estimate ionic liquids ecotoxicity EC50(Vibrio fischeri). J. Mol. Liq. 152, 28-33. https://doi.org/10.1016/j.molliq.2009.12.008.

Ma, S., Lv, M., Deng, F., Zhang, X., Zhai, H., Lv, W., 2015. Predicting the ecotoxicity of ionic liquids towards Vibrio fischeri using genetic function approximation and least squares support vector machine. J. Hazard. Mater. 283, 591-598. https://doi.org/10. 1016/j.jhazmat.2014.10.011.

Markiewicz, M., Jungnickel, C., Markowska, A., Szczepaniak, U., Paszkiewicz, M., Hupka, J., 2009. 1-methyl-3-octylimidazolium chloride-sorption and primary biodegradation analysis in activated sewage sludge. Molecules. 14, 4396-4405. https://doi.org/ 10.3390 /molecules14114396.

Matzke, M., Stolte, S., Thiele, K., Juffernholz, T., Arning, J., Ranke, J., Welz-Biermann, U., Jastorff, B., 2007. The influence of anion species on the toxicity of 1-alkyl-3-methylimidazolium ionic liquids observed in an (eco)toxicological test battery. Green Chem. 9, 1198. https://doi.org/10.1039/b705795d.

Messali, M., Aouad, M., El-Sayed, W., Al-Sheikh Ali, A., Ben Hadda, T., Hammouti, B., 2014. New eco-friendly 1-Alkyl-3-(4-phenoxybutyl) imidazolium-based ionic liquids derivatives: a green ultrasound-assisted synthesis, characterization, antibacterial activity and POM analyses. Molecules. 19, 11741-11759. https://doi.org/10.3390/ molecules190811741.

Montalbán, M.G., Hidalgo, J.M., Collado-González, M., Díaz Baños, F.G., Víllora, G., 2016. Assessing chemical toxicity of ionic liquids on Vibrio fischeri : correlation with structure and composition. Chemosphere. 155, 405-414. https://doi.org/10.1016/j. chemosphere.2016.04.042.

Neumann, J., Cho, C.-W., Steudte, S., Köser, J., Uerdingen, M., Thöming, J., Stolte, S., 2012. Biodegradability of fluoroorganic and cyano-based ionic liquid anions under aerobic and anaerobic conditions. Green Chem. 14, 410-418. https://doi.org/10. 1039/C1GC16170A.

Oliveira, M.V.S., Vidal, B.T., Melo, C.M., de, R., de Miranda, C.M., Soares, C.M.F., Coutinho, J.A.P., Ventura, S.P.M., Mattedi, S., Lima, Á.S., 2016. (Eco)toxicity and biodegradability of protic ionic liquids. Chemosphere. 147, 460-466. https://doi. org/10.1016/J.CHEMOSPHERE.2015.11.016.

Opallo, M., Lesniewski, A., 2011. A review on electrodes modified with ionic liquids. J. Electroanal. Chem. Lausanne (Lausanne) 656, 2-16. https://doi.org/10.1016/J. JELECHEM.2011.01.008.

Papaiconomou, N., Estager, J., Traore, Y., Bauduin, P., Bas, C., Legeai, S., Viboud, S., Draye, M., 2010. Synthesis, Physicochemical Properties, and Toxicity Data of New Hydrophobic Ionic Liquids Containing Dimethylpyridinium and Trimethylpyridinium Cations †. J. Chem. Eng. Data 55, 1971-1979. https://doi.org/10.1021/je9009283.

Paternò, A., D’Anna, F., Musumarra, G., Noto, R., Scirè, S., 2014. A multivariate insight into ionic liquids toxicities. RSC Adv. 4, 23985-24000. https://doi.org/10.1039/ C4RA03230F.

Paternò, A., Bocci, G., Goracci, L., Musumarra, G., Scirè, S., 2016a. Modelling the aquatic toxicity of ionic liquids by means of VolSurf in silico descriptors. SAR QSAR Environ. Res. 27, 1-15. https://doi.org/10.1080/1062936X.2015.1120778.

Paternò, A., Bocci, G., Cruciani, G., Fortuna, C.G., Goracci, L., Sciré, S., Musumarra, G., 2016b. Cyto- and enzyme toxicities of ionic liquids modelled on the basis of VolSurf + descriptors and their principal properties. SAR QSAR Environ. Res. 27, 221-244. https://doi.org/10.1080/1062936X.2016.1156571.

Peric, B., Sierra, J., Martí, E., Cruañas, R., Garau, M.A., Arning, J., Bottin-Weber, U.,
Stolte, S., 2013. (Eco)toxicity and biodegradability of selected protic and aprotic ionic liquids. J. Hazard. Mater. 261, 99-105. https://doi.org/10.1016/j.jhazmat. 2013.06.070.

Pernak, J., Sobaszkiewicz, K., Mirska, I., 2003. Anti-microbial activities of ionic liquids. Green Chem. 5, 52-56. https://doi.org/10.1039/b207543c.

Pernak, J., Goc, I., Mirska, I., 2004. Anti-microbial activities of protic ionic liquids with lactate anion. Green Chem. 6, 323. https://doi.org/10.1039/b404625k.

Pernak, J., Borucka, N., Walkiewicz, F., Markiewicz, B., Fochtman, P., Stolte, S., Steudte, S., Stepnowski, P., 2011. Synthesis, toxicity, biodegradability and physicochemical properties of 4-benzyl-4-methylmorpholinium-based ionic liquids. Green Chem. 13, 2901. https://doi.org/10.1039/c1gc15468k.

Pernak, J., Syguda, A., Mirska, I., Pernak, A., Nawrot, J., Pr??dzyńska, A., Griffin, S.T., Rogers, R.D., 2007. Choline-derivative-Based ionic liquids. Chem. A Eur. J. 13, 6817-6827. https://doi.org/10.1002/chem.200700285.

Pernak, J., Kalewska, J., Ksycińska, H., Cybulski, J., 2001a. Synthesis and anti-microbial activities of some pyridinium salts with alkoxymethyl hydrophobic group. Eur. J. Med. Chem. 36, 899-907. https://doi.org/10.1016/S0223-5234(01)01280-6.

Pernak, J., Rogoża, J., Mirska, I., 2001b. Synthesis and antimicrobial activities of new pyridinium and benzimidazolium chlorides. Eur. J. Med. Chem. 36, 313-320. https:// doi.org/10.1016/S0223-5234(01)01226-0.

Pieraccini, D., Chiappe, C., Intorre, L., Pretti, C., 2007. Ecotoxicity of ionic liquids in an aquatic environment. Thermodyn. Solubility Environ. Issues. 259-278. https://doi. org/10.1016/B978-044452707-3/50016-1.

Plechkova, N.V., Seddon, K.R., 2008. Applications of ionic liquids in the chemical industry. Chem. Soc. Rev. 37, 123-150. https://doi.org/10.1039/B006677J.

N. V. Plechkova, K.R. Seddon, Ionic liquids completely uncoiled: critical expert overviews, n.d.

Postleb, F., Stefanik, D., Seifert, H., Giernoth, R., 2013. BIOnic Liquids: Imidazoliumbased ionic liquids with antimicrobial activity. Z. Naturforsch. 68, 1123-1128. https://doi.org/10.5560/ZNB.2013-3150.

Pretti, C., Chiappe, C., Baldetti, I., Brunini, S., Monni, G., Intorre, L., 2009. Acute toxicity of ionic liquids for three freshwater organisms: pseudokirchneriella subcapitata, Daphnia magna and Danio rerio. Ecotoxicol. Environ. Saf. 72, 1170-1176. https:// doi.org/10.1016/j.ecoenv.2008.09.010.

Ranjan, P., Athar, M., Rather, H., Vijayakrishna, K., Vasita, R., Jha, P.C., 2018a. Rational design of imidazolium based salts as anthelmintic agents. J. Mol. Liq. 255, 578-588. https://doi.org/10.1016/J.MOLLIQ.2018.02.001.

Ranjan, P., Athar, M., Rather, H., Vijayakrishna, K., Vasita, R., Jha, P.C., 2018b. Appraisal of 1-Butylimidazole-Derived ionic liquids as anthelmintic agents: an experimental and in silico approach. ChemistrySelect. 3, 7518-7526. https://doi.org/10.1002/slct. 201800402.

Ranjan, P., Athar, M., Vijayakrishna, K., Meena, L.K., Vasita, R., Jha, P.C., 2018c. Deciphering the Anthelmintic Activity of Benzimidazolium Salts by Experimental and In-silico Studies. Elsevier B.Vhttps://doi.org/10.1016/j.molliq.2018.07.029.

Ranke, J., Mölter, K., Stock, F., Bottin-Weber, U., Poczobutt, J., Hoffmann, J., Ondruschka, B., Filser, J., Jastorff, B., 2004. Biological effects of imidazolium ionic liquids with varying chain lengths in acute Vibrio fischeri and WST-1 cell viability assays. Ecotoxicol. Environ. Saf. 58, 396-404. https://doi.org/10.1016/S01476513(03)00105-2.

Ranke, J., Stolte, S., Störmann, R., Arning, A.J., Jastorff, B., 2007a. Design of Sustainable Chemical ProductsThe Example of Ionic Liquids. https://doi.org/10.1021/ CR050942S.

Ranke, J., Müller, A., Bottin-Weber, U., Stock, F., Stolte, S., Arning, J., Störmann, R., Jastorff, B., 2007b. Lipophilicity parameters for ionic liquid cations and their correlation to in vitro cytotoxicity. Ecotoxicol. Environ. Saf. 67, 430-438. https://doi. org/10.1016/J.ECOENV.2006.08.008.

Rogers, R.D., Seddon, K.R., 2003. Chemistry. Ionic liquids-solvents of the future? Science. 302, 792-793. https://doi.org/10.1126/science.1090313.

Romero, A., Santos, A., Tojo, J., Rodríguez, A., 2008. Toxicity and biodegradability of imidazolium ionic liquids. J. Hazard. Mater. 151, 268-273. https://doi.org/10.1016/ j.jhazmat.2007.10.079.

Roy, K., Das, R.N., 2013. QSTR with extended topochemical atom (ETA) indices. 16. Development of predictive classification and regression models for toxicity of ionic liquids towards Daphnia magna. J. Hazard. Mater. 254-255, 166-178. https://doi. org/10.1016/j.jhazmat.2013.03.023.

Roy, K., Das, R.N., Popelier, P.L.A., 2014. Quantitative structure-activity relationship for toxicity of ionic liquids to Daphnia magna: aromaticity vs. Lipophilicity. Chemosphere. 112, 120-127. https://doi.org/10.1016/j.chemosphere.2014.04.002.

Roy, K., Kar, S., Das, R.N., 2015a. Understanding the Basics of QSAR for Applications in Pharmaceutical Sciences and Risk Assessment. Academic Press, an imprint of Elsevier.

Roy, K., Das, R.N., Popelier, P.L.A., 2015b. Predictive QSAR modelling of algal toxicity of ionic liquids and its interspecies correlation with Daphnia toxicity. Environ. Sci. Pollut. Res. 22, 6634-6641. https://doi.org/10.1007/s11356-014-3845-0.

Rybinska, A., Sosnowska, A., Grzonkowska, M., Barycki, M., Puzyn, T., 2016. Filling environmental data gaps with QSPR for ionic liquids: modeling n-octanol/water coefficient. J. Hazard. Mater. 303, 137-144. https://doi.org/10.1016/j.jhazmat. 2015.10.023.

Salam, M.A., Abdullah, B., Ramli, A., Mujtaba, I., 2016. Structural feature based computational approach of toxicity prediction of ionic liquids: cationic and anionic effects on ionic liquids toxicity. J. Mol. Liq. 224, 393-400. https://doi.org/10.1016/j.molliq. 2016.09.120.

Salar-García, M.J., Ortiz-Martínez, V.M., Hernández-Fernández, F.J., de los Ríos, A.P., Quesada-Medina, J., 2017. Ionic liquid technology to recover volatile organic compounds (VOCs). J. Hazard. Mater. 321, 484-499. https://doi.org/10.1016/j.jhazmat. 2016.09.040. 
Samorì, C., Pasteris, A., Galletti, P., Tagliavini, E., 2007. Acute toxicity of oxygenated and nonoxygenated IMIDAZOLIUM-BASED IONIC liquids to Daphnia magna and Vibrio Fischeri. Environ. Toxicol. Chem. 26, 2379. https://doi.org/10.1897/07-066R2.1.

Samorì, C., Malferrari, D., Valbonesi, P., Montecavalli, A., Moretti, F., Galletti, P., Sartor, G., Tagliavini, E., Fabbri, E., Pasteris, A., 2010. Introduction of oxygenated side chain into imidazolium ionic liquids: evaluation of the effects at different biological organization levels. Ecotoxicol. Environ. Saf. 73, 1456-1464. https://doi.org/10.1016/J. ECOENV.2010.07.020.

Siedlecka, E.M., Stepnowski, P., 2009. The effect of alkyl chain length on the degradation of alkylimidazolium- and pyridinium-type ionic liquids in a Fenton-like system. Environ. Sci. Pollut. Res. 16, 453-458. https://doi.org/10.1007/s11356-008-0058-4.

Sosnowska, A., Grzonkowska, M., Puzyn, T., 2017. Global versus local QSAR models for predicting ionic liquids toxicity against IPC-81 leukemia rat cell line: the predictive ability. J. Mol. Liq. 231, 333-340. https://doi.org/10.1016/J.MOLLIQ.2017.02.025.

Sosnowska, A., Barycki, M., Zaborowska, M., Rybinska, A., Puzyn, T., 2014. Towards designing environmentally safe ionic liquids: the influence of the cation structure. Green Chem. 16, 4749-4757. https://doi.org/10.1039/C4GC00526K.

Stasiewicz, M., Mulkiewicz, E., Tomczak-Wandzel, R., Kumirska, J., Siedlecka, E.M., Gołebiowski, M., Gajdus, J., Czerwicka, M., Stepnowski, P., 2008. Assessing toxicity and biodegradation of novel, environmentally benign ionic liquids (1-alkoxymethyl3-hydroxypyridinium chloride, saccharinate and acesulfamates) on cellular and molecular level. Ecotoxicol. Environ. Saf. 71, 157-165. https://doi.org/10.1016/J. ECOENV.2007.08.011.

Stolte, S., Steudte, S., Igartua, A., Stepnowski, P., 2011. The biodegradation of ionic liquids - the view from a chemical structure perspective. Curr. Org. Chem. 15 1946-1973. https://doi.org/10.2174/138527211795703603.

Stolte, S., Matzke, M., Arning, J., Böschen, A., Pitner, W.-R., Welz-Biermann, U., Jastorff, B., Ranke, J., 2007. Effects of different head groups and functionalised side chains on the aquatic toxicity of ionic liquids. Green Chem. 9, 1170. https://doi.org/10.1039/ b711119c.

Stolte, S., Steudte, S., Areitioaurtena, O., Pagano, F., Thöming, J., Stepnowski, P., Igartua, A., 2012. Ionic liquids as lubricants or lubrication additives: an ecotoxicity and biodegradability assessment. Chemosphere. 89, 1135-1141. https://doi.org/10. 1016/j.chemosphere.2012.05.102.

Stolte, S., Arning, J., Bottin-Weber, U., Matzke, M., Stock, F., Thiele, K., Uerdingen, M., Welz-Biermann, U., Jastorff, B., Ranke, J., 2006. Anion effects on the cytotoxicity of ionic liquids. Green Chem. 8, 621. https://doi.org/10.1039/b602161a.

Sushko, I., Novotarskyi, S., Körner, R., Pandey, A.K., Rupp, M., Teetz, W., Brandmaier, S., Abdelaziz, A., Prokopenko, V.V., Tanchuk, V.Y., Todeschini, R., Varnek, A., Marcou, G., Ertl, P., Potemkin, V., Grishina, M., Gasteiger, J., Schwab, C., Baskin, I.I., Palyulin, V.A., Radchenko, E.V., Welsh, W.J., Kholodovych, V., Chekmarev, D., Cherkasov, A., Aires-de-Sousa, J., Zhang, Q.-Y., Bender, A., Nigsch, F., Patiny, L., Williams, A., Tkachenko, V., Tetko, I.V., 2011. Online chemical modeling environment (OCHEM): web platform for data storage, model development and publishing of chemical information. J. Comput. Aided Mol. Des. 25, 533-554. https://doi.org/10.1007/ s10822-011-9440-2.

Thuy Pham, T.P., Cho, C.-W., Yun, Y.-S., 2010. Environmental fate and toxicity of ionic liquids: a review. Water Res. 44, 352-372. https://doi.org/10.1016/j.watres.2009. 09.030 .

Torrecilla, J.S., García, J., Rojo, E., Rodríguez, F., 2009. Estimation of toxicity of ionic liquids in Leukemia Rat Cell Line and Acetylcholinesterase enzyme by principal component analysis, neural networks and multiple lineal regressions. J. Hazard. Mater. 164, 182-194. https://doi.org/10.1016/J.JHAZMAT.2008.08.022.

UFT Merck Ionic Liquids Biological Effects Database, (n.d.). http://www.il-eco.uft.unibremen.de/login.php?page $=$ home\&view $=$ ionicliquids\&lang $=$ en $($ accessed Octobe
9, 2018).

Venkata Nancharaiah, Y., Reddy, G.K.K., Lalithamanasa, P., Venugopalan, V.P., 2012 The ionic liquid 1-alkyl-3-methylimidazolium demonstrates comparable antimicrobial and antibiofilm behavior to a cationic surfactant. Biofouling. 28, 1141-1149. https://doi.org/10.1080/08927014.2012.736966.

Ventura, S.P.M., Gonçalves, A.M.M., Gonçalves, F., Coutinho, J.A.P., 2010. Assessing the toxicity on [C3mim] [Tf2N] to aquatic organisms of different trophic levels. Aquat. Toxicol. 96, 290-297. https://doi.org/10.1016/j.aquatox.2009.11.008.

Ventura, S.P.M., Marques, C.S., Rosatella, A.A., Afonso, C.A.M., Gonçalves, F., Coutinho, J.A.P., 2012. Toxicity assessment of various ionic liquid families towards Vibrio fischeri marine bacteria. Ecotoxicol. Environ. Saf. 76, 162-168. https://doi.org/10. 1016/j.ecoenv.2011.10.006.

Ventura, S.P.M., Gonçalves, A.M.M., Sintra, T., Pereira, J.L., Gonçalves, F., Coutinho, J.A.P., 2013. Designing ionic liquids: the chemical structure role in the toxicity. Ecotoxicology. 22, 1-12. https://doi.org/10.1007/s10646-012-0997-x.

Viboud, S., Papaiconomou, N., Cortesi, A., Chatel, G., Draye, M., Fontvieille, D., 2012 Correlating the structure and composition of ionic liquids with their toxicity on Vibrio fischeri: a systematic study. J. Hazard. Mater. 215-216, 40-48. https://doi. org/10.1016/J.JHAZMAT.2012.02.019.

Wang, C., Wei, Z., Wang, L., Sun, P., Wang, Z., 2015. Assessment of bromide-based ionic liquid toxicity toward aquatic organisms and QSAR analysis. Ecotoxicol. Environ. Saf. 115, 112-118. https://doi.org/10.1016/j.ecoenv.2015.02.012.

Wang, X., Ohlin, C.A., Lu, Q., Fei, Z., Hu, J., Dyson, P.J., 2007. Cytotoxicity of ionic liquids and precursor compounds towards human cell line HeLa. Green Chem. 9, 1191. https://doi.org/10.1039/b704503d.

Yan, F., Shang, Q., Xia, S., Wang, Q., Ma, P., 2015. Topological study on the toxicity of ionic liquids on Vibrio fischeri by the quantitative structure-activity relationship method. J. Hazard. Mater. 286, 410-415. https://doi.org/10.1016/j.jhazmat.2015. 01.016.

Yan, F., Xia, S., Wang, Q., Ma, P., 2012. Predicting toxicity of ionic liquids in acetylcholinesterase enzyme by the quantitative structure-Activity relationship method using topological indexes. J. Chem. Eng. Data 57, 2252-2257. https://doi.org/10. 1021/je3002046.

Yoo, B., Zhu, Y., Maginn, E.J., 2016. Molecular mechanism of ionic-liquid-Induced membrane disruption: morphological changes to bilayers, multilayers, and vesicles. Langmuir. 32, 5403-5411. https://doi.org/10.1021/acs.langmuir.6b00768.

Yu, Y., Lu, X., Zhou, Q., Dong, K., Yao, H., Zhang, S., 2008. Biodegradable naphthenic acid ionic liquids: synthesis, characterization, and quantitative structure-biodegradation relationship. Chem. - A Eur. J. 14, 11174-11182. https://doi.org/10.1002/ chem. 200800620.

Yu, M., Wang, S.-H., Luo, Y.-R., Han, Y.-W., Li, X.-Y., Zhang, B.-J., Wang, J.-J., 2009. Effects of the 1-alkyl-3-methylimidazolium bromide ionic liquids on the antioxidant defense system of Daphnia magna. Ecotoxicol. Environ. Saf. 72, 1798-1804. https:// doi.org/10.1016/J.ECOENV.2009.05.002.

Yu, J., Zhang, S., Dai, Y., Lu, X., Lei, Q., Fang, W., 2016. Antimicrobial activity and cytotoxicity of piperazinium- and guanidinium-based ionic liquids. J. Hazard. Mater. 307, 73-81. https://doi.org/10.1016/j.jhazmat.2015.12.028.

Zhang, S., Sun, N., He, X., Lu, X., Zhang, X., 2006. Physical properties of ionic liquids: database and evaluation. J. Phys. Chem. Ref. Data 35, 1475-1517. https://doi.org/ 10.1063/1.2204959.

Zhao, Y., Zhao, J., Huang, Y., Zhou, Q., Zhang, X., Zhang, S., 2014. Toxicity of ionic liquids: database and prediction via quantitative structure-activity relationship method. J. Hazard. Mater. 278, 320-329. https://doi.org/10.1016/j.jhazmat.2014. 06.018. 